\title{
PERDEBATAN ANTARA KAUM MENGENAI ISU KERAKYATAN SEBELUM MERDEKA
}

\begin{abstract}
Abdul Halim Ramli
Abstract

This article examines the debate revolving around the issue of citizenship between 1946 and 1957. This article will examine the introduction of the Malayan Union citizenship, the subsequent Federation of Malaya Agreement in 1948 and the debate surrounding the citizenship issue. The second part of the article will concentrate the debate surrounding the citizenship during the formulation of the 1957 federal constitution. The issue become controversial debate between Malays and non-Malays before Independence and triggered strained feeling among two ethnic groups. However the issue finally resolved by negotiation and compromise among them. This article show the issue of citizenship has led Malays fear of losing their right after Independence. However, intensive negotiations among the leaders of three ethnic groups had been able to solve this issue successfully. The non-Malays have finally received the citizenship right they fought for so long. Their struggle for citizenship right is essential for legalization of political right to ensure protection and survival their future in this country.
\end{abstract}

\section{Pengenalan}

Isu hak kerakyatan kaum bukan Melayu sebelum merdeka, terutama selepas berakhirnya Perang Dunia Kedua menjadi isu yang kontroversi dan sensitif dalam kalangan perbagai kaum, terutama dalam kalangan orang Melayu ${ }^{1}$. Hak kerakyatan ini telah menjadi matlamat perjuangan kaum bukan Melayu terutama selepas penubuhan Persekutuan Tanah Melayu pada tahun 1948. Penubuhan Persekutuan Tanah Melayu 1948 dilihat oleh kaum bukan Melayu lebih banyak meninggalkan kesan negatif terutama dalam perjuangan mereka untuk mendapatkan hak kerakyatan dan kesaksamaan hak, sebaliknya ia dilihat lebih banyak memberi perlindungan dan mengukuhkan kedudukan bangsa Melayu di negara ini. Lantas perjuangan kaum bukan Melayu bagi mendapatkan hak kerakyatan menimbulkan tindak balas daripada orang Melayu.

Sikap orang Melayu terhadap tuntutan kaum bukan Melayu tersebut terbahagi kepada dua golongan. Golongan pertama menentang tuntutan tersebut disebabkan kebimbangan mereka terhadap ancaman masa depan kaum bukan Melayu terhadap kedudukan orang Melayu terutama dalam 
aspek politik dan ekonomi. Lebih-lebih lagi mereka berpendapat bahawa negara ini adalah pusaka turun menurun orang Melayu yang tidak boleh digadaikan bagi memenuhi tuntutan kaum bukan Melayu tersebut. Manakala orang Melayu yang berpendirian sederhana (pemimpin UMNO), sedia memberikan hak kerakyatan kepada kaum bukan Melayu setelah mereka diyakini tentang kesetiaan kaum bukan Melayu yang tidak berbelah bahagi terhadap negara ini, lebih-lebih lagi kaum bukan Melayu bersetuju mengiktiraf dan menerima hak istimewa orang Melayu, kedudukan Islam sebagai agama Persekutuan, bahasa Melayu sebagai bahasa kebangsaan dan kedudukan raja-raja Melayu. Peristiwa sejarah tawar menawar tersebut disebut sebagai 'persetujuan bersejarah' dan merupakan quid pro quo yang dirakamkan berlaku dalam proses penggubalan Perlembagaan negara bermula seawal tahun 1955. Akhirnya orang Melayu telah menerima hak kerakyatan kaum bukan Melayu selepas kaum bukan Melayu mengiktiraf hak-hak orang Melayu yang sah dari sudut perlembagaan sebagai kaum bumiputera di negara ini.

\section{Kerakyatan Malayan Union: Penentangan Orang Melayu}

Apabila kerajaan Inggeris membuat pengumuman untuk menubuhkan Malayan Union pada bulan Oktober 1945, bagi menggabungkan negerinegeri Melayu di Semenanjung, mewujudkan satu bentuk pentadbiran yang berpusat dan melonggarkan syarat-syarat kerakyatan bukan Melayu, maka orang Melayu telah bangkit menentang gagasan tersebut. ${ }^{2} \mathrm{Di}$ bawah Malayan Union, orang Melayu akan menjadi warganegara secara automatik, manakala orang bukan Melayu yang ingin menjadi warganegara perlu memenuhi beberapa kelayakan seperti dilahirkan di Tanah Melayu dan Singapura. Mereka juga boleh diberikan hak kewarganegaraan apabila tinggal 10 daripada 15 tahun di negeri-negeri Melayu atau lima tahun di Singapura. ${ }^{3}$ Kelonggaran syarat kerakyatan kepada kaum Cina dan India adalah sebagai inisiatif kepada mereka untuk memutuskan hubungan mereka dengan negara leluhur mereka dan menganggap Tanah Melayu sebagai tanah air mereka sendiri. ${ }^{4}$ James Allen pula berpendapat, Malayan Union merupakan satu usaha Inggeris untuk menghukum orang Melayu dan memberi "reward" kepada orang Cina. Perkara ini ada kaitannya dengan sokongan orang Melayu terhadap pemerintahan Jepun selepas British mengaku kalah dan ketidakaktifan orang Melayu dalam membantu Inggeris menentang Jepun. Sebaliknya British terasa terhutang budi dengan orang Cina kerana banyak membantu mereka mempertahankan Malaya dari serangan tentera Jepun dan berkerjasama dengan tentera British menentang Jepun melalui Malayan Peoples'Anti-Japanese Army (MPAJA) semasa Tanah Melayu dijajah oleh Jepun. ${ }^{5}$ 
Penentangan orang Melayu terhadap Malayan Union bukan sahaja raja-raja Melayu diminta menyerahkan kedaulatan di negeri masingmasing kepada Baginda Raja Inggeris, tetapi juga dilihat oleh orang Melayu sebagai satu ancaman terhadap hak orang Melayu dan sebaliknya hanya berfaedah kepada orang bukan Melayu. Justeru itu, orang Melayu telah bangkit menentang Malayan Union. ${ }^{6}$ Tunjuk perasaan orang Melayu yang pertama menentang Malayan Union ialah di Kelantan ketika Mac Micheal tiba di Kota Bharu pada penghujung Disember 1945. Kedatangan Mac Micheal ke Kelantan telah disambut dengan demontrasi kira-kira 10,000 orang Melayu dengan melaungkan kata-kata "Malaya kepunyaan orang Melayu. Kami tidak mahu bangsa lain diberikan hakhak dan keistimewaan yang dimiliki oleh orang Melayu".

Kemuncak bantahan orang Melayu ialah apabila Mesyuarat Kongres Seluruh Melayu diadakan di Kuala Lumpur pada 1-4 Mac 1946 yang meluluskan beberapa ketetapan. Antaranya menghantar telegram ke Menteri Jajahan Inggeris yang mengandungi isi bantahan orang Melayu terhadap Malayan Union dan menggesa kerajaan Inggeris berfikir panjang sebelum melaksanakan gagasan tersebut. ${ }^{8}$ Sekiranya gagasan Malayan Union ini berjaya dilaksanakan, maka raja-raja Melayu akan kehilangan kedaulatan mereka, British akan dapat memerintah secara langsung di negara ini dan akan wujud hak kewarganegaraan yang sama untuk semua kaum. Kalau ini berlaku, kerajaan British tidak akan lagi mengiktiraf orang Melayu sebagai rakyat peribumi yang mempunyai hak yang lebih berbanding kaum lain. Orang Melayu juga akan kehilangan dominasi mereka dalam politik dan kehilangan identiti mereka dalam jangka masa panjang. ${ }^{9}$ Di samping itu, sekiranya Malayan Union dapat dilaksanakan secara keseluruhannya, maka ia akan menjadikan Malaya sebagai "Malayan" nation-state, bukannya "Malay" nation-state. ${ }^{10}$

Walaupun Malayan Union memberikan kelebihan kepada kaum bukan Melayu terutama dalam hak kerakyatan, namun kaum Cina pada mulanya tidak memperlihatkan sokongan mereka terhadap gagasan tersebut, tidak seperti yang dijangkakan oleh Inggeris. Akhbar-akhbar Cina tidak memberikan komen mereka terhadap Malayan Union sehinggalah pada 31 Januari 1946. ${ }^{11}$ Kaum Cina lebih bimbang terhadap permasalahan ekonomi dan ganguan hak sivil mereka pada waktu tersebut. Majoriti kaum Cina melihat cadangan perlembagaan Malayan Union tidak membawa apa makna, kecuali jika ia memberi kesan terhadap kehidupan peribadi mereka sendiri. Manakala dalam kalangan ahli politik yang mempunyai kesedaran untuk memperjuangkan nasib kaum Cina juga berbeza pendapat. Ahli Kuomintang dan orang Cina yang dilahirkan di negara China tidak menunjukkan minat mereka terhadap Kertas Putih cadangan Malayan Union. Kesetiaan politik mereka hanyalah kepada negara asal mereka. ${ }^{12}$ 
Bagi mereka, penerimaan terhadap kewarganegaraan yang dicadangkan melalui Malayan Union hanya akan menimbulkan masalah terhadap status kewarganegaraan mereka sebagai warganegara China. Menurut akhbar Chung Hwa sekiranya kaum Cina inginkan hak kewarganegaraan Malaya, mereka harus secara terbuka mengisytihar atau secara tidak langsung menyatakan bahawa mereka sudah terpisah dari negara asal mereka. Keadaan ini agak menyukarkan orang Cina untuk menerima kewarganegaraan Malayan Union sedangkan mereka ingin terus mengekalkan kewarganegaraan China. Manakala akhbar Cina yang lain seperti Modern Daily telah menentang peranan sultan-sultan Melayu sebagai pemimpin tradisional dan ketua agama bagi Malayan Union. Akhbar Sin Min Chu dalam laporannya bertarikh 24 Januari 1946 secara tegas mengkritik Malayan Union yang disifatkannya masih jauh dalam memperkasa status politik rakyat Malaya dan hanya "consolidated Britain's hold on Malaya and Singapore" ${ }^{13}$ Manakala golongan radikal Cina yang diwakili oleh Parti Komunis Malaya (PKM) telah menolak Malayan Union kerana ia tidak menyediakan satu pilihan raya yang menyebabkan kuasa Gabenor dianggap berlebihan dan pemisahan Singapura dianggap tidak logik dari sudut politik dan ekonomi. Golongan radikal Cina ini memperjuangkan penubuhan sebuah negara sosialis. Manakala golongan Cina yang moderat tidak begitu menentang Malayan Union kerana tertarik dengan peluang untuk mendapatkan kewarganegaraan melalui gagasan tersebut. ${ }^{14}$

Manakala kaum India juga tidak banyak memberikan respons mereka terhadap gagasan Malayan Union. Editor akhbar kaum India tidak menyentuh cadangan Malayan Union sehinggalah pada 1 Februari 1946. Ini disebabkan penumpuan akhbar Tamil pada waktu tersebut adalah terhadap isu kekurangan makanan, peningkatan harga barangan dan industri. Bagaimanapun, isu Malayan Union mula menjadi tumpuan komuniti India apabila akhbar Jananayagam (akhbar golongan sayap kiri kaum India) pada 23 Mac 1946 telah mengkritik Malayan Union dengan menyifatkannya sebagai satu metod untuk memperteguhkan pentadbiran British dan menjajah negara ini. Ia adalah satu rancangan untuk memecah belahkan Malaya mengikut kehendak kaum imperialis. ${ }^{15}$

Akhbar India lain yang turut mengecam Malayan Union ialah The Tamil Press, Malaya Nanban, Tamil Murasu dan lain-lain. Sikap komuniti India yang berpecah dalam isu Malayan Union berlaku disebabkan penumpuan politik kaum India sehingga pertengahan tahun 1946 adalah terhadap perkembangan politik yang berlaku di India. Bagaimanapun mulai pertengahan tahun 1946, majoriti kaum India telah mengalu-alukan rancangan untuk memberikan kewarganegaraan Malaya yang sama kepada semua kaum dan pemusatan kerajaan. Apabila MIC (Malaysian 
Indian Congress) ditubuhkan pada bulan Ogos 1946, barulah kaum India melalui MIC membincangkan isu-isu yang berkaitan dengan perlembagaan dan kesan Malayan Union terhadap kaum India di negara ini. ${ }^{16}$

MIC seperti UMNO (United Malays National Organization) juga telah menentang Malayan Union kerana gagasan ini dilaksanakan dengan paksaan tanpa persetujuan rakyat asal negara ini. Pandangan umum dalam kalangan komuniti India ketika itu ialah Malaya adalah negara Melayu dan hakikat ini mestilah dikekalkan. Kaum India juga tidak menerima sebarang pembaharuan perlembagaan yang tidak diterima oleh orang Melayu sendiri. Justeru itu, John Thivy (Presiden MIC) dalam ucapannya pada 7 Jun 1947 ketika Mesyuarat Tahunan MIC di Kuala Lumpur telah meyakinkan orang Melayu bahawa kaum India;

Would never appeal over the heads of the Malays to the British for any particular right or privilege in the task of establishing a constitution for Malaya; if we do so we would be sowing the seeds of communal dissensions. ${ }^{17}$

\section{Hak Kerakyatan Persekutuan Tanah Melayu 1948: Penentangan Kaum Bukan Melayu}

Pada bulan Disember 1946, satu perjanjian telah dicapai bagi membubarkan Malayan Union dan digantikan dengan Persekutuan Tanah Melayu yang diwujudkan pada 1 Februari 1948. ${ }^{18}$ Menurut Comber, Persekutuan Tanah Melayu merupakan asas kepada Perlembagaan Malaysia hari ini dan penubuhannya merupakan kejayaan kepada orang Melayu. Ini disebabkan Perjanjian Persekutuan Tanah Melayu menyatakan bahawa Pesuruhjaya Tinggi Inggeris akan bertanggungjawab menjaga hak istimewa orang Melayu dan kepentingan sah kaum bukan Melayu. ${ }^{19}$ Perjanjian Persekutuan merupakan tolak ansur orang Melayu dan Cina. Sungguhpun orang Cina tidak dimasukkan dalam Jawatankuasa Kerja (Working Commitee) tetapi pandangan mereka telah diperolehi sebelum Perjanjian itu menjadi undangundang. Menurut Comber lagi, orang Melayu bersetuju memberi kerakyatan Persekutuan kepada mereka yang mencurahkan taat setia yang tidak berbelah bagi kepada negara ini mengikut syarat yang telah disebutkan dalam Perjanjian tersebut. Orang Melayu kebanyakannya telah berpuas hati dengan perlembagaan baru ini tetapi tidak berapa mendapat sambutan dari kaum bukan Melayu disebabkan ketidakpuasan hati mereka mengenai undang-undang kerakyatan Persekutuan ${ }^{20}$ yang ketat. ${ }^{21}$

Peruntukan mengenai syarat-syarat kerakyatan di bawah perjanjian Persekutuan telah menyebabkan orang bukan Melayu sukar untuk memperoleh hak kerakyatan berbanding kaum Melayu. Menurut Oong, 
Perjanjian Persekutuan merupakan satu polisi kerajaan British yang pertama kali membuat perbezaan antara orang Melayu dan bukan Melayu. Ia bukan sahaja memberi definisi siapakah orang Melayu ${ }^{22}$ tetapi secara tidak langsung telah membahagikan orang Cina kepada tiga kelompok, iaitu Cina Negeri Selat (warganegara British), Cina yang dilahirkan di Malaya yang telah dibaratkan atau separuh-diasimilasi dan Cina asing (pendatang). Komuniti Cina Selat yang menjadi rakyat British di Penang dan Melaka diterima sebagai warganegara Persekutuan. Manakala Cina yang dilahirkan di Malaya, di mana ibu bapa mereka juga lahir di sini, mereka layak mendapat hak kerakyatan mengikut "kuat kuasa undang-undang".

Namun begitu, sebahagian besar dari kelompok Cina asing boleh mendapatkan hak kerakyatan berasaskan kepada permohonan, tetapi harus memenuhi syarat seperti mempunyai pengetahuan bahasa Melayu dan bahasa Inggeris yang memadai. Akibatnya, sebahagian besar kaum Cina asing (pendatang) tetap menjadi pendatang di Malaya, manakala golongan pendatang dari Indonesia yang telah diiktiraf oleh Sultan Melayu sebagai rakyat Malaya bersama dengan orang Melayu telah diberi kerakyatan berdasarkan "kuat kuasa undang-undang". ${ }^{23}$ Bagaimanpun, di bawah Perjanjian Persekutuan, berdasarkan annual report bagi tahun 1950, seramai 3,120,000 orang telah menjadi warganegara melalui kuat kuasa undang-undang, di mana 2,500,000 orang adalah orang Melayu, 350,000 Cina dan 225,000 adalah orang India, Pakistan dan Ceylon. Selepas dicampur dengan bilangan mereka yang memperoleh kerakyatan berdasarkan permohonan, jumlah warganegara Persekutuan dianggarkan sebanyak 3,275,000, di mana 2,500,000 adalah orang Melayu, 500,000 Cina dan 230,000 adalah orang India, Pakistan dan Cyelon. ${ }^{24}$

Reaksi dan penentangan kaum bukan Melayu terhadap Perjanjian Persekutuan menurut Khong dapat dibahagikan kepada tiga, iaitu penentangan golongan radikal Parti Komunis Malaya (PKM), konservatif Cina (Dewan Perniagaan Cina) dan minoriti (seperti MIC, Malayan Democratic Union (MDU) dan lain-lain). Faktor penentangan PKM terhadap Perjanjian Persekutuan, antaranya disebabkan ketidakpuasan hati mereka mengenai syarat kewarganegaraan yang ketat di mana PKM berpendapat bahawa kaum bukan Melayu sepatutnya memperoleh hak kerakyatan dengan mudah dan mempunyai hak yang sama dengan kaum Melayu. Kerajaan British sepatutnya bertindak menyatukan kaum Melayu dengan kaum Cina. Sekiranya kaum Cina didiskriminasikan dan tidak mendapat kerakyatan, maka perpaduan kaum agak sukar untuk dibina. ${ }^{25}$

Justeru itu, setelah Persekutuan Tanah Melayu yang diisytiharkan secara rasmi penubuhannya pada 1 Februari 1948, Parti Komunis Malaya 
(PKM) telah mengumumkan kempen penentangannya terhadap kerajaan secara gerila dan bersenjata bagi mendapatkan kuasa memerintah. ${ }^{26}$ Sebelum mengisytiharkan penentangannya terhadap kerajaan British secara gerila, PKM dilihat sebagai tenaga penggerak yang menyatukan gerakan kiri terutama mempergunakan AMCJA-PUTERA bagi menentang cadangan Persekutuan. ${ }^{27}$ Menurut maklumat dari Malayan Security Service, pada awal bulan Ogos 1946, PKM telah mengeluarkan satu arahan sulit bagi mewujudkan "gerakan bersama" di bawah satu "organisasi yang bersatu" untuk melakukan "emansipasi kaum di Malaya" dari pemerintahan British. Gerakan tersebut merupakan satu peluang bagi PKM untuk mewujudkan ketidakpuasan hati rakyat terhadap polisi penjajah. Justeru itu, PKM telah mengarahkan supaya ahli-ahlinya mewujudkan kerjasama dengan tiga kumpulan kaum di Malaya dan pelbagai pertubuhan politik serta menyokong gerakan antiPersekutuan yang akan menjejaskan pemerintahan British. ${ }^{28}$

Bagi menjayakan rancangan Persekutuan, MacDonald dalam satu konfrensi sulit pada bulan Jun 1947, telah mengisytiharkan bahawa PKM adalah "musuh nombor satu" British. Untuk melemahkan pengaruh PKM, kerajaan British perlu menyelesaikan dengan segera rancangan Persekutuan. Manakala menurut Edward Gent, sekiranya rancangan Persekutuan dilewatkan pelaksanaannya, maka ia akan membolehkan PKM menjadi "dangerously strengthened and encouraged" ${ }^{29}$ Dengan sebab itu, British tidak perlu memenuhi tuntutan Dewan Perniagaan Cina Malaysia (ACCM) yang mendesak supaya diwujudkan sebuah Suruhanjaya Diraja bagi membuat semakan terhadap Perjanjian Persekutuan kerana ia bukan sahaja mewujudkan suasana ketidaktentuan, tetapi juga akan menjadi alat PKM. ${ }^{30}$

Walau bagaimanapun, pelaksanaan segera rancangan Persekutuan tidak dapat membendung pengaruh PKM, bahkan gerakan mereka semakin agresif. Kekacauan dan keganasan yang pertama PKM dilakukan di Perak (Sungai Siput) ${ }^{31}$ pada bulan Jun 1948 dan akhirnya merebak ke seluruh Tanah Melayu sehingga mendesak kerajaan Inggeris mengumumkan pemerintahan darurat di seluruh Persekutuan pada 12 Julai 1948. Pemberontakan PKM telah menyebabkan banyak kemusnahan harta benda dan nyawa sehingga membawa kerajaan Inggeris mengharamkan pergerakan PKM. PKM telah diharamkan pada 23 Julai 1948. Pengharaman PKM telah membawa pemimpin kaum Cina memikirkan alternatif lain bagi menyalurkan aspirasi perjuangan mereka yang membawa kepada penubuhan MCA pada 27 Februari 1949. ${ }^{32}$

Manakala reaksi golongan konservatif Cina seperti Dewan Perniagaan Cina menurut Khong, tidaklah secara total menolak Perjanjian Persekutuan yang dilihat oleh mereka sebagai menjaga kepentingan orang 
Melayu sebagai penduduk peribumi Tanah Melayu. Namun, mereka telah menolak syarat kerakyatan yang memerlukan 15 tahun bermastautin di Tanah Melayu yang dianggap sebagai menghalang lebih ramai dari kalangan kaum Cina mendapat hak-hak mereka yang sah di negara ini. ${ }^{33}$ Penentangan golongan konservatif Cina terhadap cadangan Persekutuan terserlah melalui memorandum yang dihantar oleh Pan-Malayan Chinese Chambers of Commerce (ACCC) kepada Setiausaha Tanah Jajahan Inggeris yang diputuskan melalui konfrensi yang mereka adakan pada 23 Februari 1947. Memorandum tersebut bertajuk Memorandum on the Constitutional Proposal for Malaya yang dirangka oleh Tan Cheng Lock dan dihantar melalui telegram pada 28 Februari 1947. Memorandum tersebut telah menyuarakan penentangan Dewan Perniagaan Cina Malaysia terhadap cadangan Persekutuan yang disifatkan mereka sebagai "is undemocratic and retrograde in structure and conception, and thoroughly inconsistent with His Majesty's Goverment's pledge to facilitate and ensure the program of the people of Malaya towards unity and ultimate self-goverment...".34

Cadangan mewujudkan Persekutuan Tanah Melayu telah dikritik oleh Dewan Perniagaan Cina Malaysia sebagai meminggirkan orang Cina dan kaum bukan Melayu dianggap sebagai golongan yang tidak dikehendaki. Mereka seterusnya menuduh British melaksanakan polisi "pecah dan perintah" dan "Malaya untuk orang Melayu". Ini disebabkan orang Melayu mendapat hak kerakyatan yang mudah, tetapi menafikan hak orang Cina dan bukan Melayu yang dilahirkan di Malaya, kecuali kedua ibu bapa mereka dilahirkan di negara ini dan tinggal di negara ini dalam jangka masa tidak kurang dari 15 tahun. ${ }^{35}$

Bertitik tolak dari hakikat tersebut, memorandum tersebut telah mencadangkan supaya pemerolehan hak kerakyatan secara automatik perlu dikaji semula dan syarat kerakyatan Persekutuan berdasarkan kuat kuasa hendaklah diberikan kepada (i) sesiapa sahaja yang dilahirkan dan menjadi pemastautin tetap di mana-mana negeri Persekutuan tanpa diskriminasi kaum, (ii) sebarang individu di mana bapa, ketika ia dilahirkan adalah rakyat Persekutuan (iii) sesiapa yang sudah menjadi residen biasa dalam mana-mana negeri Persekutuan 10 tahun dari 15 tahun. ${ }^{36}$ Memorandum yang dihantar kepada Setiausaha Tanah Jajahan British tersebut turut mendesak supaya diwujudkan segera sebuah Suruhanjaya Diraja. Suruhanjaya tersebut perlu datang ke Malaya untuk mengkaji keseluruhan kandungan Perlembagaan Persekutuan dan membuat perbincangan dengan semua pihak di Malaya. ${ }^{37}$

Manakala MIC (minoriti) turut menjadi salah sebuah organisasi yang awal menentang draf Perjanjian Persekutuan. ${ }^{38}$ Pada tahun 1947, MIC melalui keahliannya dalam AMCJA telah membuat kempen untuk menentang cadangan Perlembagaan Persekutuan Tanah Melayu. MIC 
telah menyuarakan pandangan mereka bahawa Malaya adalah sebuah negara majmuk bukan hanya negara bagi orang Melayu semata-mata. Oleh sebab itu, hak kewarganegaraan yang sama rata perlu diberikan kepada semua kaum. MIC telah meluluskan satu resolusi pada bulan Mac 1948 untuk memulaukan Perlembagaan Persekutuan dan memecat mana-mana ahlinya yang menganggotai Majlis Perundangan. Bagaimanapun pemulauan tersebut telah mendapat tentangan dari beberapa cawangan penting $\mathrm{MIC} .{ }^{39}$

\section{Perjuangan Menuntut Hak Kerakyatan Melalui Jawatankuasa Hubungan Antara Kaum (CLC)}

Walaupun gerakan anti-Persekutuan digerakkan oleh kaum bukan Melayu melalui PKM, AMCJA, Dewan Perniagaan Cina dan pelancaran hartal atau mogok ekonomi yang dianjurkan oleh gabungan AMCJAPUTERA pada 20 Oktober 1947 bagi membantah Perjanjian Persekutuan Tanah Melayu, namun ia tidak menghalang kerajaan British mengisytiharkan penubuhan Persekutuan Tanah Melayu pada 1 Februari 1948. Meskipun gerakan anti-Persekutuan telah gagal dan tuntutan bukan Melayu supaya British menyemak kembali undang-undang kerakyatan Persekutuan tidak dilayan oleh British, namun perjuangan kaum bukan Melayu untuk mendapat hak kerakyatan yang lebih memihak kepada mereka tetap diteruskan. Misalnya, Tan Cheng Lock telah menghabiskan 10 tahun dari masanya (iaitu semenjak dari tahun 1947 hingga 1957) menentang syarat kerakyatan yang terkandung dalam Perjanjian Persekutuan dengan memperjuangkan syarat kerakyatan berdasarkan jus soli untuk orang Cina. Perjuangan tersebut menampakkan kejayaannya pada tahun $1951^{40}$ dan $1957 .{ }^{41}$

Kejayaan tersebut mula tercapai melalui peranan aktif yang dimainkan oleh Tan Cheng Lock dan pemimpin elit Cina yang lain melalui Jawatankuasa Hubungan Kaum (CLC) dan penubuhan MCA pada tahun 1949. Tan Cheng Lock yang menganggotai Jawatankuasa Hubungan Kaum bersama dengan lima wakil kaum Cina yang lain dan masingmasing satu wakil dari kaum India, Eurasian, Ceylon dan Eropah ${ }^{42}$ telah menggunakan medium tersebut untuk memperjuangkan hak kerakyatan bukan Melayu. Manakala British pula telah menggunakan penubuhan CLC sebagai satu cara untuk meneutralkan penentangan orang Melayu terhadap tuntutan bukan Melayu mengenai hak kerakyatan Malaya. Mac Donald telah menggunakan faktor kebimbangan orang Melayu terhadap Parti Komunis Malaya (PKM) yang mungkin merampas kuasa, kecuali kerajaan British mengambil tindakan bagi menyelesaikan isu kerakyatan bagi mengurangkan sokongan orang Cina terhadap PKM yang menjanjikan hak politik dan kerakyatan yang sama untuk semua kaum 
jika mereka mendapat kuasa. Justeru itu, Mac Donald menegaskan bahawa kerajaan British terpaksa menggunakan janji yang sama kepada kaum bukan Melayu bagi menarik sokongan mereka. Alasan tersebut telah menyebabkan pemimpin UMNO bersetuju dengan tuntutan MCA bagi meliberalkan peruntukan-peruntukan mengenai hak kerakyatan. ${ }^{43}$

Perbincangan mengenai hak kerakyatan telah menjadi salah satu isu utama yang dibincangkan di dalam perjumpaan Jawatankuasa CLC pada 29 hingga 31 Disember 1949 di Pulau Pinang. Menurut Tan Cheng Lock, mesyuarat CLC pada 30 Disember telah membincangkan cadangan untuk meminda Perlembagaan Persekutuan 1948 berkaitan dengan soal kewarganegaraan. Bagaimanapun, cadangan tersebut telah dikritik oleh sebahagian dari ahli CLC Melayu dengan menyifatkan keinginan beriburibu orang Cina untuk mendapatkan kewarganegaraan Persekutuan disebabkan kebimbangan mereka untuk kembali ke negara China yang ketika itu telah menjadi sebuah negara komunis. Mereka mendakwa keinginan orang Cina untuk mendapatkan kewarganegaraan Persekutuan bukan disebabkan perasaan kesetiaan mereka terhadap negara ini. Justeru itu, Tan Cheng Lock dalam mesyuarat tersebut telah merayu kepada wakil Melayu supaya mempunyai sikap timbang rasa kepada komuniti Cina, membuangkan sikap keraguan dan sikap tidak mempercayai masyarakat Cina di negara ini. Menurut Tan Cheng Lock lagi, sekiranya orang Melayu menyakini orang Cina ikhlas dan ingin menumpahkan kesetiaan mereka kepada negara ini dan orang Cina pula dapat membuktikan kesetiaan mereka maka orang Melayu akan dapat menerima orang Cina sebagai warganegara Malaya. Akhirnya, pada akhir mesyuarat tersebut, ahli jawatankuasa CLC telah sebulat suara menerima prinsip jus soli (undangundang tempat lahir) digunakan dalam soal pemberian kewarganegaraan kepada kaum bukan Melayu.

Prinsip jus soli perlu diperkenalkan dengan secepat mugkin di setiap negeri-negeri Melayu supaya semua orang yang berketurunan Asia atau Eurasian yang dilahirkan di negeri tersebut menjadi rakyat Raja dan dengan demikian membolehkan mereka menjadi rakyat Persekutuan pada masa yang sama. ${ }^{44}$ Jawatankuasa CLC telah mencadangkan supaya diwujudkan dua jenis kewarganegaraan iaitu melalui undang-undang dan melalui pendaftaran. Kewarganegaraan melalui kuat kuasa undangundang mestilah melalui ujian yang mudah dan sesiapa yang dilahirkan di Persekutuan layak menerima kerakyatan Persekutuan. Manakala kewarganegaraan melalui pendaftaran boleh dipohon oleh sesiapa sahaja yang bermastautin selama 15 tahun dalam Persekutuan, di samping mempunyai perwatakan yang baik, mempunyai pengetahuan yang mencukupi sama ada dalam bahasa Melayu atau Inggeris sekadar yang boleh difahami) dan perlu membuat pengisytiharan kesetiaan (mengangkat sumpah taat setia) terhadap Persekutuan. ${ }^{45}$ 
Penerimaan cadangan kewarganegaraan yang mengguna pakai prinsip jus soli oleh ahli jawatankuasa CLC secara sebulat suara tersebut adalah merupakan kompromi atau tolak ansur yang amat penting dilakukan oleh Dato' Onn terhadap tuntutan Tan Cheng Lock. Ia dibuat setelah pemimpin-pemimpin Cina bersetuju tentang "implimentasi polisi berkenaan hak-hak keistimewaan kaum Melayu" dan "keistimewaan ekonomi" bagi kaum Melayu diakui. ${ }^{46}$

Cadangan yang dikemukakan oleh Jawatankuasa Hubungan Kaum supaya diadakan undang-undang kerakyatan bagi Persekutuan dan negeri-negeri Melayu dengan syarat yang mudah dan longgar telah menimbulkan kemarahan dari ahli-ahli UMNO dan orang Melayu. Umpamanya, Nik Mahmod bin Hj. Abdul Majid Kelantan, di dalam Warta Negara bertarikh 10 Mei 1950 berpendapat, sekiranya kaum bukan Melayu diterima sebagai warganegara Malaya yang sama taraf dengan orang Melayu, maka tindakan berikut perlu dilakukan. ${ }^{47}$

1. Kesemua bangsa bukan Melayu tidak dibenarkan lagi masuk menduduki Tanah Melayu melainkan bangsa British sahaja.

2. Kesemua bangsa Melayu Sarawak, Brunei, Borneo, Indonesia, Siam, Kemboja dan mana-mana negeri atau pulau di seluruh dunia dibenarkan masuk menduduki Tanah Melayu menjadi anak Tanah Melayu.

3. Kesemua sekolah-sekolah bangsa asing mestilah ditutup dan tidak dibenarkan lagi melainkan hanyalah sekolah-sekolah bahasa Melayu dengan sekolah bahasa Inggeris sahaja.

4. Kesemua bangsa mestilah lulus Darjah Lima Sekolah Melayu baharulah boleh ia masuk sekolah Inggeris dan barulah boleh diterima bekerja di pejabat-pejabat kerajaan dan menjadi kakitangan kerajaan.

5. Kesemua bangsa asing yang telah menjadi anak rakyat Tanah Melayu tidak boleh pulang ke negerinya dan harta bendanya tidak boleh dihantarkan ke negerinya dan dimestikan ia putus persaudaraan dengan bangsa di negerinya.

6. Tiap-tiap gudang perniagaan bangsa asing yang memakai kuli dan kakitangannya, mestilah setengah kulinya atau kakitangannya itu dipakai orang Melayu.

Sementara itu, UMNO pula terpaksa membuat cadangan balas mengenai syarat-syarat menjadi rakyat Persekutuan dan rakyat Raja. Cadangan balas itu telah dibentangkan dalam Persidangan Agung UMNO pada 20 dan 21 Mei 1950 di Kuala Lumpur. Dalam Persidangan itu, Dato' Onn telah berucap dengan panjang lebar menolak kritikan terhadap cadangan tersebut dan syarat-syarat kerakyatan yang dikemukakan oleh Jawatankuasa Hubungan Antara Kaum. Antara yang kuat menentang 
cadangan kerakyatan tersebut ialah Persekutuan Penuntut-penuntut Pelajaran Tinggi yang menuduh Dato' Onn belot dan khianat. Dalam persidangan itu juga terdapat dalam kalangan ahli-ahli UMNO yang menentang dengan keras cadangan tersebut dan mendesak supaya cadangan itu ditangguhkan dahulu kerana para perwakilan belum mendapat masa yang mencukupi untuk melihat dan mengkaji undangundang kerakyatan seperti yang telah dicadangkan oleh CLC. ${ }^{48}$

Rasional dari pengujudan undang-undang kerakyatan yang menimbulkan kontroversi itu telah dihuraikan dengan lanjut oleh Dato' Onn dalam perjumpaan pada 20 dan 21 Mei 1951 tersebut. Menurut Dato' Onn', undang-undang kerakyatan di negeri-negeri Melayu belum wujud lagi bagi menentukan siapakah yang menjadi rakyat Raja atau rakyat bagi negeri-negeri Melayu. Dengan ketiadaan syarat-syarat kerakyatan dalam undang-undang negeri-negeri Melayu agak sukar untuk menentukan kerakyatan seseorang itu. Dengan sebab itu menurut Dato' Onn, adalah mustahak setiap buah negeri mengadakan Undangundang Kerakyatan negeri itu bagi menentukan siapa yang dikatakan rakyat negeri itu. Kata Dato' Onn lagi; "Oleh kerana, selagi tidak ada undang-undang yang semacam itu, maka pada hari ini, ada beratus ribu orang dari keturunan atau yang datangnya dari Indonesia tetapi sudah mengaku duduk dan berkehendak duduk di sini selamanya, tidak boleh diakui menjadi rakyat negeri kita. Begitukah kehendak dan tujuan orang Melayu?. Saya sendiri tidak faham" ${ }^{\prime 4}{ }^{9}$

Undang-Undang Kerakyatan itu juga merupakan satu perakuan dari Jawatankuasa Hubungan Antara Kaum (CLC) yang menyebutkan oleh kerana setiap negeri-negeri Melayu itu merupakan negeri Melayu beraja dan mempunyai kerajaan, maka secara logiknya ia berhak mempunyai rakyatnya sendiri. Oleh kerana, negeri-negeri Melayu tidak mempunyai undang-undang kerakyatan mereka sendiri, maka akan terpakai undangundang dunia iaitu yang menggunakan prinsip jus soli. Sekiranya prinsip ini digunapakai dalam undang-undang negeri, maka ia melibatkan 1.2 juta kaum Cina, 270,000 kaum India dan lebih kurang 45,000 kaum-kaum lain yang boleh menuntut menjadi kerakyatan British ataupun rakyat raja-raja Melayu disebabkan mereka dilahirkan di dalam Persekutuan Tanah Melayu. ${ }^{50}$

Lanjutan dari cadangan Dato' Onn, satu Persidangan Agung UMNO pada 10 hingga 11 Jun 1950 telah diadakan secara khusus bagi membincangkan undang-undang kerakyatan yang dicadangkan oleh UMNO untuk dikemukakan kepada kerajaan British. Persidangan tersebut bermula dengan agak panas. Terdapat ucapan-ucapan perwakilan yang menuduh, menghentam Dato' Onn dan menolak cadangan kerakyatan tersebut. Akhirnya, pada hari kedua persidangan 
tersebut Dato' Onn telah mengumumkan peletakan jawatan sebagai Presiden UMNO. Pengumuman peletakan jawatan Dato' Onn sebagai Presiden UMNO telah menimbulkan suasana kelam kabut. Dalam ucapan pada hari terakhir persidangan, Dato' Onn telah menjelaskan sebab-sebab peletakan jawatannya disebabkan perbezaan pandangan mengenai cadangan kerakyatan kaum bukan Melayu dengan sebahagian ahli UMNO. Peletakan jawatan ini bagi menjaga perpaduan orang Melayu dan UMNO kerana beliau dituduh membawa sesuatu perkara yang tidak boleh diterima oleh orang Melayu sendiri. Kata Dato' Onn'; "Tuduhan ini amat berat yang saya sendiri tidak dapat menerimanya. Saya mempunyai darah Melayu. Dari dikekalkan tuduhan-tuduhan itu, terlebih baik saya tunjukkan kepada bangsa dan tanah air saya dengan mengundurkan diri dari UMNO". ${ }^{51}$

Bagi Dato' Onn, soal mengadakan undang-undang kerakyatan adalah satu persoalan dasar dan pokok yang perlu diselesaikan. Ia adalah satu realiti politik yang perlu diterima oleh orang Melayu. Katanya lagi, "jika partinya tidak mahu menerima dasar yang dibawanya itu tidak ada lain jalan baginya melainkan meletakan jawatan dan membuka kepada lain orang menjalankan UMNO itu menurut dasar yang dipersetujui dan dikehendaki oleh Persidangan Agung". Walaupun selepas itu, Persidangan telah meluluskan usul yang memberikan kepercayaan penuh kepada Dato' Onn dan meminta beliau menarik balik perletakan jawatannya, namun beliau tetap tidak berganjak dengan pendirian asalnya itu. ${ }^{52}$ Bagaimanapun, dalam persidangan UMNO pada 27 hingga 29 Ogos, 1950, Dato' Onn telah dipilih semula sebagai Presiden UMNO tetapi setahun kemudian beliau keluar dari UMNO dan menubuhkan sebuah parti baru yang dinamakan Parti Malaya Merdeka atau IMP.

Dalam persidangan Agung UMNO pada 25 dan 26 Ogos 1951, iaitu persidangan yang terakhir baginya, Dato' Onn telah membayangkan untuk menubuhkan sebuah parti baru yang tidak bersifat perkauman dengan harapan untuk mendapat sokongan dan mengukuhkan kedudukannya dalam kalangan kaum bukan Melayu. Beliau telah menerangkan sebab utama beliau keluar dari UMNO dan menubuhkan sebuah parti baru adalah kerana beliau ingin mewujudkan perpaduan dan perhubungan yang baik antara kaum di Tanah Melayu serta hendak mengikat kaum-kaum lain yang hendak menumpahkan taat setia mereka dan menjadi warganegara di negara ini. Di samping itu, faktor penolakan cadangan beliau khususnya oleh ahli UMNO sendiri mengenai undangundang kerakyatan yang memberi hak kepada bukan Melayu menjadi warganegara negara ini turut menjadi faktor beliau meninggalkan UMNO dan menubuhkan sebuah parti baru. ${ }^{53}$ 
Perasaan tidak puas hati kaum bukan Melayu terhadap syarat-syarat kerakyatan dalam Perjanjian Persekutuan Tanah Melayu 1948 yang menghalang mereka untuk mendapatkan hak kerakyatan dengan mudah, di samping cadangan yang dikemukakan oleh Jawatankuasa CLC bagi meliberalkan syarat kerakyatan telah mempengaruhi British membuat pindaan terhadap Perjanjian tersebut. Hasilnya pada bulan Jun, 1951 proposal mengenai isu kerakyatan telah dibawa ke dalam Majlis Undangan Persekutuan. Namun ia tidak diluluskan kerana bantahan dari ahli Dewan Perundangan sama ada oleh wakil Melayu dan bukan Melayu. Bagi ahli Dewan Perundangan Melayu, cadangan tersebut begitu liberal, manakala bagi kaum bukan Melayu, cadangan tersebut terlalu ketat. Isu tersebut kemudiannya telah dirujuk untuk penilaian yang lebih lanjut lagi oleh Select Commitee. Hanya pada tahun 1952, Select Commitee telah mengemukakan cadangan-cadangan mereka yang termuat dalam Ordinan Perjanjian Persekutuan (Pindaan) tahun 1952 yang memudahkan kaum bukan Melayu memperoleh hak kerakyatan. ${ }^{54}$

Walau bagaimanapun, menurut Ratnam dan Heng, pindaan tersebut masih tidak memuaskan hati kaum bukan Melayu. Bagi Ratnam, pindaan tersebut meskipun membuka pintu hak kerakyatan yang agak luas juga kepada kaum bukan Melayu, tetapi ia masih tidak dapat membentuk satu nasionaliti Malayan dan menyuburkan kesatuan rakyat. Ini disebabkan pindaan tersebut telah membentuk satu kewarganegaraan dan sembilan nasionaliti, di mana seseorang itu boleh menjadi warganegara Persekutuan sama ada melalui rakyat Raja atau rakyat United Kingdom dan tanah jajahannya serta memenuhi syarat-syarat tertentu. ${ }^{55}$ Pindaan itu juga masih menyukarkan kaum bukan Melayu memperolehi hak kerakyatan berbanding syarat kerakyatan yang terdapat dalam Malayan Union. Pindaan tersebut juga tidak dapat memuaskan hati kaum bukan Melayu kerana tuntutan mereka supaya digunakan prinsip jus soli bagi mewajarkan mereka yang dilahirkan di Tanah Melayu mendapat hak kerakyatan secara automatik tidak digunakan dalam pindaan Ordinan tersebut.

Walau bagaimanapun, pindaan tersebut telah membolehkan kirakira antara 50 dan 60 peratus orang Cina memperolehi hak kerakyatan Persekutuan dan 30 peratus orang India. ${ }^{56}$ Prinsip jus soli tidak digunakan dalam pindaan tersebut disebabkan berlakunya perubahan kepimpinan UMNO dari Dato' Onn kepada Tunku Abdul Rahman pada 25 Ogos 1951. Prinsip jus soli yang hendak digunakan dalam pemberian hak kerakyatan merupakan janji Dato' Onn kepada MCA pada tahun 1950 dan ketika beliau menganggotai Jawatankuasa CLC. Apabila Tunku Abdul Rahman mengambil alih teraju kepimpinan UMNO, beliau tidak terikat dengan janji tersebut, lebih-lebih lagi beliau tidak pernah menganggotai 
Jawatankuasa CLC dan yang lebih penting lagi prinsip jus soli tidak diterima oleh ahli-ahli UMNO. Sebagai orang yang baru dipilih sebagai Presiden UMNO, beliau tentunya tidak mahu membuat suatu keputusan yang tidak popular. ${ }^{57}$

Walaupun pindaan Ordinan Perjanjian Persekutuan 1948, menghampakan kaum bukan Melayu kerana prinsip jus soli diketepikan dalam pemberian hak kerakyatan, namun ia tidak mematahkan perjuangan mereka membuat desakan mengenainya. Tan Cheng Lock dalam ucapannya dalam Mesyuarat Tahunan General Committe MCA di Singapura pada 27 Disember 1953 telah membuat penegasan sekali lagi bahawa kaum Cina tidak boleh diragukan kesetiaan mereka terhadap negara ini. Kaum Cina menurutnya datang untuk tinggal di negara ini dan menjadikan negara ini sebagai tempat tinggal mereka yang tetap. Tan Cheng Lock juga menegaskan ketika negara ini jatuh ke tangan pemerintahan Jepun yang zalim, orang Cina masih menunjukkan kesetiaan yang tidak berbelah bahagi terhadap negara ini. Adalah satu metos mengatakan orang Cina menguasai kekayaan negara, padahal orang Cina hanya memiliki kurang dari 20 peratus ladang getah dan tidak lebih dari 25 peratus pemilik lombong bijih timah, sedangkan pemilik yang terbesar industri tersebut adalah orang Eropah. Orang Cina menguasai kekayaan Malaya adalah lebih kecil dari apa yang dipunyai oleh orang Eropah, meskipun bilangan orang Cina lebih ramai. Kebanyakan orang Cina masih lagi miskin seperti kebanyakan orang Melayu. Tan Cheng Lock telah memberi ingatan bahawa "we are living in an age "when any prolonged attempt of any race nation or class or sex to dominate another can only bring destruction to both". ${ }^{8}$

\section{Isu Kerakyatan Dalam Pilihan Raya Persekutuan 1955}

Pilihan raya Persekutuan yang pertama telah diadakan pada 27 Julai 1955. Dalam pilihan raya tersebut, pihak parti Perikatan telah mengeluarkan manifestonya pada bulan Mei 1955 setelah dibincangkan dengan panjang lebar oleh Majlis Tertinggi Perikatan. ${ }^{59}$ Manifesto yang dikeluarkan oleh Perikatan ketika itu tidaklah membuat satu pendirian yang tegas dan tetap mengenai dasar kerakyatan. Ini disebabkan pemberian hak kewarganegaraan mengikut prinsip jus soli telah ditentang dengan hebat oleh orang Melayu. ${ }^{60}$

Bagi mendapat sokongan dari orang Melayu dalam pilihan raya tersebut, UMNO telah berjanji untuk mempertahankan hak istimewa orang Melayu dan tidak membuat janji yang khusus mengenai hak kerakyatan bukan Melayu dalam Manifesto tersebut. MCA tidak membantah tindakan tersebut kerana mereka telah berpuas hati dengan jaminan yang diberikan kepada mereka oleh UMNO mengenai hak 
kerakyatan. Sebaliknya, pemimpin MCA telah berpuas hati dengan pengisyitiharan manifesto mengenai isu pendidikan Cina (termasuk janji menyemak kembali Ordinan Pelajaran 1952) ${ }^{61}$ yang boleh menarik sokongan pengundi kaum Cina kepada Perikatan. ${ }^{62}$ Tambahan pula, jumlah pengundi Cina ketika itu hanya mewakili 11.2 peratus dari jumlah pengundi yang membuatkan MCA bersikap membisu dalam soal ini. Bagaimanapun, Perikatan telah mengambil jalan tengah di mana masalah kewarganegaraan hendaklah diselesaikan oleh satu Suruhanjaya bebas yang merangka perlembagaan negara. ${ }^{63}$ Perkara ini dinyatakan dalam manifesto Perikatan yang menyebutkan:

Perikatan berpendapat bahawa oleh kerana Persekutuan yang telah merdeka harus mengadakan perubahan-perubahan perlembagaan, suruhanjaya bebas yang akan mengkaji perubahan-perubahan perlembagaan itu mestilah juga memeriksa dengan teliti masalah yang berhubung dengan penduduk-penduduk dari bangsa-bangsa asing yang besar jumlahnya. Suruhanjaya itu haruslah diberi tugas kewajipan menyiasat masalah ini dan membuat syor bagaimana masalah ini boleh diselesaikan dengan memuaskan hati. ${ }^{64}$

\section{Hak Kerakyatan Sebagai Testamen Politik Perikatan Tahun 1956}

Walaupun dalam pilihanraya Persekutuan 1955, MCA dan MIC mengalah kepada kehendak UMNO untuk tidak memasukkan soal kerakyatan dalam manifesto mereka, bagi meraih sokongan 84 peratus pengundi Melayu, namun tuntutan bukan Melayu terhadap pemakaian prinsip jus soli dalam soal kerakyatan terus diperjuangkan. Perkara ini terserlah melalui Memorandum Perikatan kepada Suruhanjaya Reid yang disifatkan sebagai Testamen Politik Perikatan yang mengandungi 20 muka surat telah disediakan oleh beberapa pemimpin penting UMNO, MCA dan MIC di antara bulan April dan September 1956. ${ }^{65}$ Dalam aspek kerakyatan, memorandum ini telah menegaskan bahawa Perlembagaan patutlah menyediakan satu undang-undang kebangsaan yang akan dapat membina sebuah negara Persekutuan yang merdeka, aman dan stabil. Bagi mencapai matlamat ini, maka adalah amat mustahak diadakan satu undang-undang taraf kebangsaan yang akan mewujudkan kebangsaan yang tunggal.

Dalam memorandum tersebut, Perikatan telah mengesyorkan bahawa kesemua mereka yang menjadi rakyat Persekutuan melalui kuat kuasa undang-undang, pendaftaran atau naturalisasi pada tarikh pengisytiharan kemerdekaan mestilah diterima sebagai warganegara yang pertama sekali bagi Malaysia. Begitu juga bagi mereka yang dilahirkan di Melaka dan Pulau Pinang (yang dianggap sebagai warganegara British melalui undang-undang yang ada) sebelum dari 
tarikh pengisytiharan kemerdekaan patutlah menjadi warganegara Malaysia pada dan selepas pengisytiharan kemerdekaan itu dibuat. Mereka juga diberikan hak memilih sama ada mereka hendak memegang terus taraf kerakyatan British di dalam tempoh satu tahun daripada tarikh kemerdekaan dengan cara membuat ikrar melucutkan taraf kerakyatan Malaysia. Perikatan juga mencadangkan supaya mereka yang dilahirkan di Malaysia pada dan selepas daripada tarikh pengisytiharan kemerdekaan patutlah menjadi warganegara Malaysia. Bagi warganegara yang dilahirkan di Malaysia yang ibu bapa mereka adalah rakyat asing pada atau selepas daripada tarikh kemerdekaan, pihak UMNO mencadangkan supaya mereka diberi kebebasan untuk memilih kerakyatan selepas mereka berumur 21 tahun.

Walau bagaimanapun, cadangan yang dikemukakan oleh UMNO ini tidak dipersetujui oleh MCA dan MIC. Memorandum itu juga menetapkan syarat kerakyatan bagi mereka yang dilahirkan di luar Malaysia sedangkan bapanya adalah warganegara Malaysia adalah layak menjadi warganegara melalui cara pendaftaran. Manakala isteri seorang warganegara Malaysia berhak didaftarkan sebagai warganegara melalui cara permohonan. Anak-anak yang berumur kurang dari 21 tahun yang bapanya pada tarikh dilahirkan belum lagi menjadi rakyat Persekutuan menurut Perjanjian Persekutuan Tanah Melayu 1948, kemudian selepas itu mendapat taraf kerakyatan, hendaklah selepas daripada tarikh kemerdekaan menjadi seorang warganegara melalui cara pendaftaran, jika ia lazim tinggal di dalam negeri ini. Bagi mereka yang dilahirkan di Tanah Melayu sebelum merdeka, Perikatan berpendapat mereka berhak mendapat kerakyatan setelah didaftarkan dan memenuhi syarat seperti berumur 18 tahun atau lebih, berkelakuan baik, mengangkat sumpah taat setia kepada negara, membuat ikrar bahawa mereka akan tinggal di negara ini secara kekal, telah menduduki di sini selama 5 tahun daripada 7 tahun terdahulu dan mempunyai pengetahuan bahasa Melayu yang mudah. Bagi kaum asing yang tidak dilahirkan di negara ini, tetapi telah mendiami di sini sebelum dan sehingga kepada tarikh kemerdekaan, mereka juga layak mendapat hak kerakyatan dengan syarat sama seperti di atas, tetapi disyaratkan telah menduduki di negara ini selama 8 tahun daripada 12 tahun yang terdahulu sedikit daripada tarikh permohonan itu. ${ }^{66}$

Melalui syarat-syarat kerakyatan seperti yang dihuraikan di atas, ini bererti UMNO telah mempersetujui penggunaan prinsip jus soli seperti yang dituntut oleh kaum bukan Melayu, terutama desakan dari kaum Cina. Menurut Heng, UMNO akhirnya bersetuju dengan prinsip jus soli berasaskan tiga pertimbangan, iaitu tekanan dari British yang menginginkan penyediaan satu dasar yang kuat dan stabil untuk sebuah 
bangsa Malayan baru, keinginan untuk mendapatkan persetujuan daripada MCA mengenai hak istimewa orang Melayu dan bahasa Melayu serta penegasan kerajaan British kepada pemimpin Perikatan supaya pemimpin Melayu dan bukan Melayu perlu berkongsi kuasa memerintah serta generasi masa depan kaum Cina dan India tidak boleh dikeluarkan dari peranan mereka yang sah dalam politik, ekonomi dan budaya bagi sebuah Malaya yang merdeka. Pemimpin UMNO mempercayai bahawa British akan memberikan kemerdekaan kepada Tanah Melayu sekiranya orang bukan Melayu diberikan hak kerakyatan Tanah Melayu. ${ }^{67}$

Sebenarnya kompromi UMNO terhadap tuntutan bukan Melayu terhadap prinsip jus soli dalam soal kerakyatan dan kelonggaran dalam soal bahasa sebelum Memorandum Perikatan dikeluarkan, telah menimbulkan bantahan yang hebat dari orang Melayu dan sebahagian ahli-ahli UMNO. Umpamanya, Datuk Raja Mohammad Hanifah (UMNO Negeri Sembilan) telah memberi amaran kepada pemimpin UMNO supaya tidak mengalah dengan tuntutan kaum bukan Melayu melalui perundingan dalam parti Perikatan mengenai perlembagaan yang berkaitan isu kerakyatan, hak istimewa orang Melayu dan bahasa. Manakala pengarang Akhbar Warta Negara bertarikh 16 April 1956 pula telah mengingatkan bahawa UMNO yang ditubuhkan pada tahun 1946 telah berjaya menyatu dan memimpin orang Melayu menentang Malayan Union. Penentangan utama orang Melayu terhadap Malayan Union disebabkan ia mahu memberikan hak kerakyatan yang sama antara orang Melayu dengan bukan Melayu. Kejayaan orang Melayu menentang sehingga terhapusnya Malayan Union tidak bererti jika sekiranya UMNO menerima tuntutan MCA mengenai prinsip jus soli dan hak kewarganegaraan yang sama. ${ }^{68}$

Kebimbangan dan penolakan orang Melayu terhadap pemakaian prinsip jus soli juga diperlihatkan melalui sebuah artikel yang disiarkan dalam Majalah Qalam bilangan 70, bulan Jun 1956. Rencana tersebut bertajuk "Kita dan Jus Soli" mengkritik tuntutan MCA mengenai prinsip jus soli yang diperjuangkan oleh Tan Cheng Lock semenjak 40 tahun lalu. Menurut rencana itu, perjuangan untuk mendapatkan hak kerakyatan tersebut dilakukan sama ada secara berlawan atau berkawan. Rencana tersebut turut menyifatkan tuntutan tersebut merupakan satu tipu muslihat. Qalam turut menyelar pemimpin UMNO dan ahli UMNO yang menyokong tuntutan tersebut dengan mengemukakan persoalan "apakah orang UMNO akan sentiasa patuh dan taat sentiasa kepada kehendak pucuk pimpinan kalau sekiranya muslihat yang dijalankan oleh pucuk pimpinan itu berlawanan dengan dasar dan kehendak orang Melayu yang diakui diperjuangkan oleh ahli-ahli UMNO?". Qalam turut mempertanggugjawabkan kepada UMNO sekiranya muslihat tersebut 
diterima yang menyebabkan bangsa Melayu terjual atau tergadai oleh orang Melayu dalam UMNO.

Prinsip jus soli bagi Qalam bermakna bangsa Melayu akan menjadi penumpang dalam negara ini. Ia juga bermakna dalam masa sepuluh atau dua puluh tahun akan datang orang Melayu akan diperintah oleh orang yang asalnya berdagang di negara ini. Hakikat ini berasaskan kepada kebimbangan Qalam terhadap peningkatan pertambahan bilangan orang dagang ini dalam masa sepuluh tahun akan datang yang menyebabkan wakil-wakil mereka dalam kerajaan akan bertambah ramai. Berasakan kepada prinsip demokrasi siapa yang banyak mereka itulah yang berkuasa, maka di ketika itu Qalam bertanya "di manakah kedudukan bangsa Melayu, di manakah kedudukan anak-anak kita kelak?, jawapannya mereka akan diperintah oleh orang dagang!. Justeru itu, Pengarang Qalam telah mengingatkan orang Melayu dan khususnya ahli UMNO supaya mengkritik apa yang dilakukan oleh pimpinan mereka dan tidak mentaati secara membabi buta terhadap keputusan yang dibuat oleh pucuk pimpinan demi kesejahteraan bangsa Melayu kerana "cemburu kepada semua perkataan dan perangai yang manis itu adalah menyelamatkan kita kemudian hari". ${ }^{69}$

Polemik yang hangat dan berterusan dalam kalangan orang Melayu dengan bukan Melayu mengenai kedudukan istimewa orang Melayu dan penggunaan prinsip jus soli dalam mendapatkan kerakyatan telah mendorong Tunku Abdul Rahman membuat ucapan ke seluruh Malaya melalui radio pada 22 April 1956. Melalui ucapannya itu Tunku telah menegaskan bahawa orang Melayu bersedia memberikan apa juga hak mereka kepada orang lain yang taat setia mereka curahkan seluruhnya kepada negara ini. Namun Tunku meminta orang bukan Melayu supaya bersikap adil, bertimbang rasa dan tuntutan mereka biarlah berpatutan. Tunku menegaskan;

Saya harap janganlah hendaknya dilupakan bahawa tidak ada putera bumi mana-mana negeri pun di dunia ini yang telah menyerahkan banyak haknya kepada orang lain seperti yang telah dilakukan oleh orang Melayu. Tidak ada putera bumi negeri lain yang menunjukkan sikap berbaik-baik kepada orang yang masuk ke negerinya sebagai yang ditunjukkan oleh orang Melayu. ${ }^{70}$

Kepada orang Melayu pula, Tunku telah merayu:

Tidak ada sebuah negeri pun di dunia ini yang telah mencapai kemerdekaannya dengan tidak memberikan banyak pegorbanan. Saya tidak menyangkal sedikit pun bahawa saudara-saudara semua akan sanggup berkorban dan terus menjaga nama baik saudara-saudara sebagai satu bangsa yang bersopan santun, bertimbang rasa dan sentiasa 
ingin bersahabat..Saya menyeru kepada semua rakyat supaya mengamalkan sifat toleransi dan menjaga semangat saling bekerjasama yang telah diamalkan oleh Perikatan dengan jayanya dalam usaha untuk mencapai kemerdekaan. ${ }^{71}$

Menurut Miller, hasil daripada ucapan Tunku tersebut, suasana tegang yang ditimbulkan oleh perasaan curiga oleh orang Melayu menjadi kendur dan masalah jus soli terus lenyap dari halaman akhbar-akhbar Melayu selama beberapa minggu berikutnya. ${ }^{72}$

\section{Kebimbangan Antara Kaum Terhadap Implikasi Laporan Reid}

Cadangan-cadangan yang dikemukakan oleh Perikatan mengenai syarat kerakyatan telah diterima oleh Suruhanjaya Reid, walaupun Suruhanjaya Reid juga ada menerima cadangan dari pihak-pihak lain. Cadangan syarat kerakyatan seperti yang terkandung dalam Memorandum Perikatan disifatkan oleh Suruhanjaya Reid sebagai terbaik bagi menguruskan keadaan yang terdapat pada masa ini dengan adil berbanding pihak lain. Ahli Suruhanjaya berpuas hati bahawa syarat-syarat tersebut adalah munasabah dan merupakan kompromi di antara pelbagai pandangan dalam parti-parti tersebut. Persetujuan tersebut adalah cara terbaik bagi melaksanakan keadilan antara kaum yang dikemukakan oleh Perikatan. Berasaskan cadangan tersebut, Suruhanjaya Reid telah membahagikan syarat kerakyatan seseorang itu kepada empat kategori. Syarat tersebut merujuk kepada seseorang yang mempunyai hak kerakyatan, dilahirkan dalam Persekutuan pada atau selepas hari Merdeka, dilahirkan dalam Persekutuan sebelum hari Merdeka dan tinggal dalam Persekutuan pada hari Merdeka dan mendiami Persekutuan pada hari Merdeka tetapi tidak dilahirkan di sini. ${ }^{73}$

Suruhanjaya Reid telah mencadangkan mereka yang telah mempunyai hak kerakyatan sebelum Merdeka, akan terus mempunyai hak-hak tersebut. Mereka yang memperolehi kerakyatan berasaskan kuat kuasa undang-undang (berasaskan klausa 126 Perjanjian Persekutuan 1948) akan terus mempunyai hak kerakyatan. Bagi mereka yang berada dalam kategori kedua (seseorang yang dilahirkan dalam Persekutuan pada atau selepas hari Merdeka), ia turut dicadangkan memperolehi hak kerakyatan berasaskan kuatkuasa undang-undang (by operation of law). Dalam soal kerakyatan kategori kedua ini, Suruhanjaya Reid menyebutkan:

We received many representation that the principle which has come to be know generally in Malaya as jus soli should be given retrospective effect. We are not satisfied that it is entirely possible or desirable to provide that all those who were born in Malaya, whatever be the date of their birth, 
wherever they may be now, and whatever be their present nationality, should retropectively made citizens of the Federation by operation of law ${ }^{74}$

Bagi kategori ketiga pula, Suruhanjaya Reid mencadangkan mereka layak diberi hak kerakyatan dengan syarat mereka telah tinggal tetap di dalam Persekutuan selama lima tahun daripada tempoh tujuh tahun yang lalu, berumur 18 tahun ke atas, berkelakuan baik dan mempunyai pengetahuan yang asas dalam bahasa Melayu. Manakala bagi mereka yang berada dalam kategori empat (seseorang yang mendiami Persekutuan pada hari Merdeka tetapi tidak dilahirkan di sini), Suruhanjaya Reid telah mencadangkan syaratnya ialah telah tinggal di dalam Persekutuan selama lapan tahun daripada tempoh 12 tahun dan mengambil ujian bahasa Melayu yang asas (rendah) bagi pemohon yang berumur lebih dari 45 tahun. ${ }^{75}$ Bagi syarat kerakyatan berdasarkan Masukan atau Naturalisation, Suruhanjaya Reid telah meletakkan enam syarat, iaitu ia sudah berumur 21 tahun, berkelakuan baik, sudah mendiami Persekutuan selama 10 tahun daripada tempoh 12 tahun sebelumnya, ia berniat hendak bermastautin di Persekutuan secara tetap, mempunyai pengetahuan bahasa Melayu yang memadai dan mengangkat sumpah kesetiaan kepada negara ini. ${ }^{76}$

Cadangan yang dibuat oleh Suruhanjaya Reid mengenai syaratsyarat kerakyatan walaupun telah diterima oleh parti-parti Perikatan tetapi dibantah oleh kaum bukan Melayu. Kaum bukan Melayu (terutama kaum Cina) telah mengkritik syarat yang ketat untuk mendapatkan kerakyatan. Bagi mereka, kesaksamaan hak-hak kerakyatan dan cara yang mudah untuk mendapatkan kerakyatan adalah asas yang utama dalam pembinaan negara, bukannya melalui syarat yang menyusahkan dan bersikap selektif dalam proses pemilihan kerakyatan. Editorial akhbar China Press pada 3 Julai 1957, telah menulis "We feel that the most important thing in citizenship is the question of loyalty, and a knowledge of the Malay language is only of secondary importance" ${ }^{77}$

Sementara itu, Dato' Onn dan Parti Negara di bawah pimpinannya dengan lantang menentang pemakaian prinsip jus soli terbuka dalam soal kerakyatan. Menurut Dato Onn:

Saya meminta kepada tiap-tiap orang Melayu yang benar-benar kasih
dan sayang kepada kaum bangsa dan negerinya supaya memikirkan
perkara ini dengan halus dan teliti supaya di belakang hari umat Melayu
yang ada pada hari ini tidakakan disumpah oleh cucu-cicit dengan sebab
tidak sedarkan kepada tanggungan kita pada masa kini dengan
mempersetujukan dan meluluskan perubahan pada masa akan datang
yang sudah tentu akan menghapuskan kekuatan dan kedudukan orang
Melayu di negara yang dikatakan Semenanjung Tanah Melayu, di negeri 
yang diakui oleh Perikatan sendiri umat Melayu dikatakan ialah Bumiputera" ${ }^{78}$

Penolakan kerakyatan jus soli terbuka oleh Dato' Onn kerana bimbang orang Melayu akan hilang kedudukannya sebagai peribumi. Ini disebabkan melalui peruntukan jus soli Suruhanjaya Reid, semua yang lahir di Tanah Melayu mempunyai kedudukan dan hak yang sama dari segi politik. Oleh itu taraf 'anak negeri' bagi orang Melayu, mengikut Dato' Onn hanya tinggal sebagai satu catatan sejarah. ${ }^{79}$ Dalam akhbar Kritik $^{80}$ bertarikh 8 Ogos 1956, Dato' Onn menzahirkan kebimbangannya, dengan pemakaian prinsip jus soli akan menyebabkan kuasa undi yang dimiliki oleh orang Melayu akan bertambah kecil. Jumlah orang Melayu yang kecil iaitu hanya 49.8 peratus pada tahun 1947 jika dibandingkan dengan bukan Melayu yang berjumlah 50.2 peratus, menjadi bertambah kecil pada tahun-tahun akan datang. Dari analisis Dato Onn', melalui peruntukan ini, orang bukan Melayu akan bertambah kepada 50.3 peratus manakala orang Melayu akan menjadi kurang iaitu 49.7 peratus. Pertambahan penduduk bukan Melayu ini menyebabkan jumlah pengundinya bertambah, iaitu daripada 16 peratus pada tahun 1955 menjadi 56.8 peratus pada tahun $1959 .{ }^{81}$ Cadangan kerakyatan yang dikemukakan oleh Suruhanjaya Reid turut ditolak oleh parti PAS. Bagi PAS, jika cadangan tersebut diterima, ia akan membawa negara ini jatuh ke dalam petaka yang hebat. Dengan membuka hak kerakyatan kepada sesiapa sahaja yang dilahirkan di negara ini maka tindakan sedemikian bagi PAS akan melahirkan warganegara yang tidak setia kepada negara ini dan merosakkan kewujudan serta kemajuan sebuah kerajaan yang merdeka. ${ }^{82}$

Penentangan Parti PAS terhadap Laporan Reid telah membawa parti tersebut mengadakan satu rapat umum di Padang Malaya, Kuala Terengganu pada 17 Mac 1957 yang dihadiri kira-kira 2,000 orang penyokong. Dalam rapat umum tersebut, Dr. Burhanuddin al-Helmy (Yang Di-pertua Agung PAS) telah menyatakan bahawa syor-syor dalam Suruhanjaya Reid tersebut merugikan bangsa Melayu dan terbabas dari keadilan. Nama bangsa Melayu telah terhapus dan jaminan kedaulatan bangsa Melayu dan agama Islam telah ditinggalkan. ${ }^{83}$ Rapat umum yang dihadiri oleh pemimpin Parti Negara, Parti Rakyat dan PAS bersama dengan orang Melayu juga telah diadakan di Padang Kelab Sultan Sulaiman, Kuala Lumpur pada 10 Mac 1957 dan diikuti rapat umum di padang Muar Club pada 16 Mac 1957. Dalam rapat umum di Padang Muar Club, Dato' Onn telah berucap (ucapannya disiarkan dalam akhbar Kritik pada 20 Mac 1957) yang menzahirkan kebimbangannya dan kebimbangan bangsa Melayu berkenaan implikasi Laporan Reid terhadap 
nasib masa depan bangsa Melayu. Dato' Onn menegaskan bahawa matlamat rapat umum yang diadakan bertujuan untuk "umat bangsa Melayu berkehendak tahu apakah akan jadinya kepada negeri-negeri Melayu dan umat bangsa Melayu di Semenanjung Tanah Melayu ini... khasnya selepas 31 haribulan Ogos hadapan ini". Dalam ucapannya, Dato' Onn telah mengimbas kembali perhimpunan keramat orang Melayu pada $12 \mathrm{hb}$. Mac 1946 di mana anak-anak Melayu telah merayu dan memberikan satu pesanan kepada ibu bapa mereka yang berbunyi:

Ayuhai bapa-bapa dan ibu-ibu, sementara kami besar-sementara kami remaja-sementara kami menjadi umat yang bertanggungjawab di atas negerinya sendiri-maka dengan hati yang suci murni-dengan menyusun jari sepuloh-kami pohonkan belalah hak kami sementara kami besar-pertahankan pusaka kami sementara kami remaja-kawalah kehormatan dan maruah kami sementara kami menjadi umat yang bertanggungjawab atas negerinya..dan kepada Tuhan kami memohonYa Allah-berkatilah oleh $\mathrm{Mu}$ dan kabulkan oleh $\mathrm{Mu}$ akan sebarang niat baik yang sedang ditaja oleh bapa-bapa dan ibu-ibu kami bagi membela dan mempertahankan hak-hak kami-perkenan oleh Mu akan sebarang langkah bagi membina sebuah kota untuk mengawal hak-hak kami sekelian. ${ }^{84}$

Dato' Onn telah meminta orang Melayu supaya mengkaji sedalamdalamnya Laporan Reid sebelum menerima laporan tersebut. Kebimbangan dan kegelisahan terhadap masa depan bangsa Melayu selepas keluarnya Laporan Reid telah ditimbulkan oleh rencana Pengarang Kritik. Menurut rencana Pengarang Kritik, "..nampaknya pada hari nyatalah umat Melayu sedang gelisah dan terharu-haru fikirannya menanti-nanti sahaja penerangan dan keterangan daripada pihak kerajaan dan dari pihak Perikatan sendiri dan dari pihak yang lain-lain juga supaya dapatlah dibandingkan sesuatu penerangan dan keterangan itu" ${ }^{\prime 8}$ Kebimbangan orang Melayu itu ada asasnya kerana menurut Dato' Onn; "the Malays would undoubtedly go astray and some might get the blessing in haven as dreamt by Chief Minister, Tengku Abdul Rahman". Manakala kaum bukan Melayu menurut Dato' Onn, akan menyetujui cadangancadangan yang dikemukakan oleh laporan tersebut kerana mereka mengharapkan perkara tersebut, sebelum penubuhan Perikatan lagi. ${ }^{86}$

Ahmad Boestamam, pemimpin parti Rakyat turut tidak meyakini keupayaan Laporan Reid dalam memenuhi hasrat bangsa Melayu. Justeru itu, menurutnya, parti Rakyat tidak menghantar apa-apa pandangan kepada Suruhanjaya Reid. Bagi Ahmad Boestaman, perlembagaan sesuatu negeri itu tidak patut dibentuk oleh orang dari luar negeri yang tidak tahu keadaan tanah air melainkan hendaklah dibentuk sendiri oleh rakyat negara ini. Apa yang telah ditegaskan oleh parti Rakyat itu 
memang berasas sebagaimana penolakan Dato' Onn dan Dr. Burhanuddin terhadap keperluan pembentukan Suruhanjaya Reid atau pihak luar bagi menggubal perlembagaan negara ini. ${ }^{87}$

Tunku Abdul Rahman memang menyedari kebimbangan orang Melayu terhadap kesan laporan Reid terhadap survival masa depan mereka dan lebih menguntungkan kaum bukan Melayu. Tunku kerap kali telah meminta orang Melayu dan semua pihak bertenang dan mengkaji serta memahami sedalam-dalamnya laporan tersebut sebelum membuat sesuatu tindakan. Gesaan Tunku itu telah disiarkan banyak kali oleh akhbar-akhbar di Tanah Melayu sejurus Laporan Reid dikeluarkan dan diedarkan kepada umum. Tunku juga meminta orang Melayu supaya berani, bersatu dan sedia membuat pengorbanan. ${ }^{88}$

Akhbar The Malay Mail pula menyifatkan Laporan Reid sebagai "The Foundation for a New Malay" yang memberi kesan kepada semua orang tanpa mengira kedudukan seseorang. Manakala menurut Ong Yoke Lin, jika laporan tersebut diluluskan, maka beribu-ribu orang yang tinggal di Persekutuan akan dapat kerakyatan, di mana pada masa lepas mereka tidak layak mendapatkannya. ${ }^{89}$ Tan Cheng Lock pula menyifatkan laporan tersebut adalah "satu dokumen yang boleh diterima", manakala Tan Siew Sin lebih berterus terang dengan menyifatkan laporan itu sebagai "nothing that the report was fair because neither the Malays nor the nonMalays were completely satisfied". ${ }^{90}$

Kebimbangan itu bukan sahaja melanda orang Melayu pada umumnya tetapi turut dirasai oleh ahli-ahli UMNO. Mereka merasakan sekiranya cadangan-cadangan yang terdapat dalam Suruhanjaya Reid jika diterima, ia akan membawa bencana besar yang boleh menimpa orang Melayu. Kegusaran tersebut telah mendorong UMNO mengadakan Persidangan Agung Tergempar pada 28 Mac 1957 di Rumah UMNO, Kuala Lumpur. Dalam persidangan yang dihadiri oleh wakil-wakil UMNO di seluruh Persekutuan dan Singapura, Tunku Abdul Rahman telah menjelaskan tujuan persidangan itu diadakan bagi memberi peluang yang seluas-luasnya kepada ahli UMNO untuk mengkaji sehalushalusnya cadangan yang terkandung dalam Suruhanjaya Reid. Tunku turut menjelaskan mengenai kemajuan yang telah dicapai dalam soal perlembagaan dan corak perlembagaan negara merdeka yang telah dipersetujui oleh ketiga-tiga parti. Tunku menyifatkan persetujuan yang dicapai oleh ketiga-tiga parti dalam Perikatan sebagai persetujuan yang besar, yang mengandungi erti yang mendalam. Persetujuan tersebut disifatkan oleh Tunku sebagai kemenangan yang besar kepada UMNO dalam perundingan dengan rakan-rakannya dalam Perikatan. ${ }^{91}$

Perbahasan mengenai syor-syor yang terkandung dalam Laporan Reid yang dilakukan oleh wakil-wakil UMNO dalam Persidangan Agung 
Tergempar UMNO tersebut berjalan dengan suasana agak tegang dan panas. UMNO Negeri Sembilan mencadangkan supaya Laporan Suruhanjaya Reid ditangguhkan sehingga selepas merdeka. Tetapi cadangan tersebut tidak mendapat sokongan ramai dan digugurkan. Akibatnya, 9 daripada 10 orang wakil UMNO yang diketuai oleh Datuk Raja Mohammad Hanifah merasa tidak berpuas hati dan bertindak menarik diri dan keluar dari persidangan tersebut setelah meminta kebenaran dari Pengerusi. ${ }^{92}$ Di akhir persidangan, satu ketetapan telah dibuat oleh Majlis Tertinggi UMNO untuk menerima keseluruhan syorsyor yang terkandung dalam Laporan Suruhanjaya Reid berserta pindaan serta tambahan-tambahan yang diputuskan melalui Perhimpunan Agung tersebut yang akan diperjuangkan untuk dimasukkan ke dalam laporan tersebut. ${ }^{93}$

Dalam Perhimpunan tersebut telah diluluskan empat usul yang utama, iaitu (1) menolak dua kerakyatan, (2) kedudukan Islam sebagai agama negara ini mestilah dijamin, (3) tidak ada tempoh tertentu bagi hak isimewa orang Melayu dan (4) bahasa Melayu dijadikan bahasa rasmi yang tunggal dan bahasa Inggeris boleh digunakan dalam urusan rasmi untuk tempoh 10 tahun. ${ }^{94}$ Lanjutan dari Persidangan Agung UMNO tersebut, UMNO Bahagian Selatan Seberang Perai telah menghantar tiga usul tambahan Perlembagaan Persekutuan yang tidak sempat dikemukakan pada Perhimpunan tersebut. Antara usul yang disampaikan ialah, "Perlembagaan Malaysia hendak-lah di-rakamkan bersama2 di-dalam Bahasa Melayu dan Inggerish sa-lewat2nya dalam tempoh 8 tahun. Sa-lepas daripada itu Bahasa Inggerish tidak di-gunakan lagi". ${ }^{95}$ Manakala Jawatankuasa Politik Perikatan dalam mesyuarat mereka pada 14 Mac 1957 telah mengambil keputusan berpegang kepada Memorandum Perikatan yang diserahkan kepada Suruhanjaya Reid pada bulan September 1956 yang lalu. Mesyuarat tersebut telah membincangkan isu dua kerakyatan, pengisytiharan Islam sebagai agama Persekutuan dan kedudukan istimewa orang Melayu. Jawatankuasa tersebut telah memberi tahu akhbar The Malay Mail bahawa, "there was complete agreement among us. We hope to submit an agreed recommendation to the National Council very shortly. There is no major point on which we cannot agree". ${ }^{96}$

\section{Kesimpulan}

Ternyata isu hak kerakyatan kaum bukan Melayu menjadi isu 'panas' yang mewarnai hubungan antara kaum sebelum merdeka. Isu tersebut kadang kala telah mencetuskan ketegangan hubungan antara kaum tetapi telah dapat diselesaikan melalui jalan perundingan yang intensif terutama dalam kalangan pimpinan tertinggi parti Perikatan. Kebijaksanaan politik Tunku Abdul Rahman dan sikap akadomatif yang diamalkan oleh 
pemimpin MCA dan MIC telah dapat meredakan ketegangan tersebut sehingga isu tersebut dapat diselesaikan melalui jalan perundingan yang menterjemahkan konsep 'give' and 'take'. Orang bukan Melayu akhirnya telah mendapat hak kerakyatan yang telah sekian lama mereka perjuangkan yang dimaktubkan dalam Perlembagaan Persekutuan 1957, walaupun tidak semua tuntutan mereka dapat dipenuhi.

Perjuangan kaum bukan Melayu untuk mendapatkan hak kerakyatan amat penting untuk pengabsahan hak politik bagi menjamin perlindungan dan survival masa depan mereka di negara ini. Manakala kaum Melayu bersedia menerima kerakyatan bukan Melayu setelah kaum bukan Melayu menerima beberapa kosensi yang mengukuhkan kedudukan orang Melayu di negara ini. Orang Melayu akhirnya menerima realiti kemajmukan masyarakat Tanah Melayu, terutama setelah mereka diyakini ketaatsetiaan kaum bukan Melayu terhadap negara ini yang tidak berbelah bagi dan keinginan yang memuncak untuk memerdekakan negara dari penjajahan serta memenuhi syarat Inggeris yang inginkan perpaduan kaum dicapai terlebih dahulu sebelum negara ini diberi kemerdekaan.

\section{Nota}

${ }^{1}$ Khong Kim Hoon, Merdeka! British Rule and the Struggle for Independence in Malaya 1945-1957, Petaling Jaya: Strategic Information Research Development, 1984, hlm. 250.

2 Ibid., hlm. 108.

3 Victor Purcell, The Chinese in Malaya, Kuala Lumpur: Oxford University Press, 1967, hal. 284.

${ }_{4}$ Khong Kim Hoong, Merdeka! British Rule and The Struggle for Independence in Malaya 1945-1957, hlm.109.

${ }_{5}^{5}$ James Allen, The Malayan Union, New Haven: Yale University: South-East Asia Studie Monograph Series, 1967, hlm. 17.

${ }^{6}$ Kunjungan Sir Harold MacMicheal ke negeri-negeri Melayu untuk mendapatkan tandatangan sultan-sultan Melayu agar menerima gagasan Malayan Union telah disambut dengan tentang kuat orang Melayu. Di Kelantan, kedatangan MacMicheal telah menyebabkan kira-kira 10,000 orang Melayu berarak di hadapan istana Sultan bagi menunjukkan penentangan mereka terhadap Malayan Union (Drs. Li Chuan Siu, Ikhtisar Sejarah Pergerakan dan Kesusateraan Melayu Moden, 1945-1965, Kuala Lumpur: Penerbitan Pustaka Antara, 1967, hlm. 80). Menurut Anwar Abdullah, pelaksanaan Malayan Union telah menyebabkan hampir-hampir mencetuskan pemberontakan bersenjata kalau tidak disebabkan kesabaran dan kebijaksanaan Dato' Onn. Dato' Onn pernah didatangi oleh beberapa orang pejuang Melayu yang telah melahirkan kepadanya hasrat mereka hendak membunuh MacMicheal, tetapi Dato' Onn menyejukkan hati mereka dan menerangkan kepada mereka bahawa perjuangan orang Melayu pada masa itu adalah perjuangan secara perlembagaan dan tindakan ganas akan hanya 
merugikan orang Melayu sendiri (Anwar Abdullah, Biografi Dato' Onn: Hidup Melayu, Bangi: Penerbit Universiti Kebangsaan, 2005, hlm. 141). Malayan Union juga telah ditentang Parti Kebangsaan Melayu Malaya (PKMM) dengan mengadakan rapat umum dan mogok yang dilancarkan di seluruh Malaya. Bantahan terhadap Malayan Union telah membawa tertubuhnya satu badan yang diberi nama PUTERA-AMCJA. PUTERA adalah gabungan pertubuhan politik dan bukan politik yang menentang Malayan Union. Manakala AMCJA terdiri daripada badan bukan Melayu yang dipengerusikan oleh Tan Cheng Lock. Hasil dari perjumpaan yang diadakan di Kuala Lumpur, PUTERA-AMCJA telah membuat draf Perlembagaan yang dikenali sebagai People's Constitution atau Perlembagaan Rakyat (Abdul Majid Salleh 2004, Memoir Abdullah Majid Salleh Dalam PKMM dan Kesatuan Buruh, Bangi: Penerbit Universiti Kebangsaan Malaysia, hlm. 72).

7 Utusan Melayu, 22 Disember 1945.

8 Untuk melihat intipati ketetapan yang diputuskan oleh Kongres yang dikirim kepada Perdana Menteri British, lihat, Ibrahim Mahmood, Sejarah Perjuangan Bangsa Melayu, Kuala Lumpur: Pustaka Antara, 1981, hlm. 89-91.

9 Khong Kim Hoong, Merdeka! hlm. 123.

${ }^{10}$ Cheah Boon Kheng, Malaysia: The Making of a Nation, Singapore: Institute of Southeast Asian Studies, 2002, hlm. 2.

${ }^{11}$ Menurut Victor Purcell, akhbar-akhbar Cina hanya menunjukkan minat yang kecil terhadap isu Malayan Union. Kritikan awal akhbar Cina terhadap Malayan Union dibuat oleh akhbar komunis,, iaitu The New Democracy (Sin Min Chu) pada 12 Oktober 1945. Akhbar ini telah mengkritik pemisahan Singapura dari Malaya lanjutan dari dasar "pecah" dan "perintah" Inggeris. Akhbar ini juga pada 3 Mei 1946 menyebutkan tidak ada gunanya dibuat perdebatan mengenai hak kewarganegaraan dan pilihanraya sekiranya masalah yang asas tidak diselesaikan terlebih dahulu. Apa yang penting ialah gangguan terhadap hakhak sivil bukannya kesaksamaan kerakyatan (Lihat Victor Purcell, The Chinese in Malaya, hlm. 286-287).

12 Ibid.,hlm. 286.

${ }^{13}$ Oong Hak Ching, Chinese Politics in Malaya 1942-55: The Dynamics of British Policy, Bangi: Penerbit Universiti Kebangsaan, 2000, hlm. 97-98.

${ }^{14}$ Rejeswary Ampavanar, The Indian Minority and Political Change in Malaya 19471957, Kuala Lumpur: Oxford University Press, 1981, hlm. 80.

${ }^{15}$ Ibid., hlm. 79-80.

${ }^{16}$ Ibid.

${ }^{17}$ Ibid., hlm. 83.

${ }^{18}$ Cheah Boon Kheng, "Perpecahan dan Perpaduan Dalam Gerakan Kemerdekaan Selepas Perang Dunia Kedua”, dlm. S. Husin Ali (ed), Kaum, Kelas dan Pembangunan, Kuala Lumpur: Persatuan Sains Sosial Malaysia, 1984, hlm. 85-87.

${ }^{19}$ Menurut Perjanjian Persekutuan Tanh Melayu 1948, Pesuruhjaya Tinggi diberi "satu tugas istimewa" untuk melindungi hak negeri-negeri Melayu atau sebarang petempatan dan hak-hak, kuasa dan kedaulatan Sultan serta melindungi kedudukan istimewa orang Melayu dan kepentingan sah kaum lain (lihat The Federation of Malay Agreement, 1948, Goverment Press, Kuala Lumpur, hlm.10). 
${ }^{20}$ Leon Comber, 13 May 1969: A History Survey of Sino-Malay Relations, Petaling Jaya: Henemann Educational Books (Asia) Ltd., hlm. 43-44.

${ }^{21}$ Mengikut Perjanjian Persekutuan 1948, hak kewarganegaraan diberikan kepada 'mana-mana rakyat...Duli Yang Maha Mulia Raja mana-mana negeri' yang ditakrifkan sebagai (i) tergolong kepada pemastautin kaum asli dalam negeri itu, atau (ii) ia seorang Melayu yang lahir dalam negeri itu atau (iii) ia seorang Melayu yang lahir di luar negeri Melayu yang bapanya menjadi rakyat raja itu di bawah mana-mana undang-undang. Selain dari dari rakyat raja, kewarganegaraan Persekutuan juga diberikan kepada (i) mana-mana rakyat British yang lahir di mana-mana satu Negeri-negeri Selat dan bermastautin secara tetap dalam Persekutuan; (ii) mana-mana rakyat British yang lahir dalam Persekutuan atau pun pada masa kelahirannya rakyat British itu adalah seorang permastautin tetap; (iii) mana-mana orang yang lahir dalam Persekutuan yang lazimnya bercakap Melayu dan menurut adat istiadat Melayu, (iv) mana-mana orang yang lahir dalam Persekutuan dan yang menjadi pemastautin tetap di Persekutuan dan (v) seorang yang bapanya adalah warganegara Persekutuan (Lihat, K.J. Ratnam, Communalism and the Political Process, Kuala Lumpur: University of Malaya Press, 1967, hlm. 76, Visu Sinnadurai, "Undang-undang Kewarganegaraan Malaysia", dlm. Tun Mohamed Suffian et al. (eds), Perlembagaan Malaysia Perkembangannya: 1957-1977, Petaling Jaya: Penerbit Fajar Bakti Sdn. Bhd.,1984, hlm. 83).

${ }^{22}$ Menurut Artikel 128, klausa (3) (b), Perjanjian Persekutuan mendefinisikan Melayu sebagai (i) kebiasaannya bertutur dalam bahasa Melayu, (ii) memeluk agama Islam, dan (iii) mengamalkan kebudayaan Melayu.

${ }^{23}$ Oong Hak Ching, Chinese Politics in Malaya, hlm. 114

${ }^{24}$ K.J. Ratnam, Communalism and the Political Process, hlm. 84.

${ }^{25}$ Khong Kim Hoong, Merdeka! hlm. 150-151.

${ }^{26}$ Beberapa orang penulis tentang gerakan komunis di negara ini sependapat bahawa PKM telah mengambil keputusan untuk melancarkan perjuangan bersenjata terhadap Inggeris sebelum penjajah Inggeris mengisytiharkan Undangundang Darurat pada pertengahan Jun 1948. Misalnya menurut Barber antara pertengahan Mei hingga awal Jun 1948, Politburo PKM yang mengadakan mesyuarat sulit di hutan Pahang telah memutuskan untuk melancarkan perjuangan bersenjata terhadap Inggeris (Lihat, Mohamad Salleh Lamry, Gerakan Kiri Melayu dalam Perjuangan Kemerdekaan, Bangi; Penerbit Universiti Kebangsaan Malaysia, 2006, hlm. 97). Dalam usaha PKM mencapai matlamat perjuangannya, mereka telah melakukan kegiatan sabotaj dan tindakan ganas. Di antara bulan Oktober 1945 hingga bulan Disember 1947, sebanyak 191 kejadian culik dan pembunuhan dilakukan oleh PKM. Dalam masa enam bulan pertama 1948, sejumlah 107 penculikan dan pembunuhan telah dilakukan oleh PKM (Lihat R.Thompson, Defeating Communist Insurgency, New York: F.A. Preager, 1966, hlm. 26-27).

${ }^{27}$ Lihat Albert Lau, The Malayan Union Controversy 1942-1948, Singapore: University Press, 1991, hlm. 246.

${ }^{28}$ Ibid., hlm. 245.

${ }^{29} \mathrm{Ibid} ., \mathrm{hlm} .246$. 
${ }^{30}$ Ibid.

${ }^{31}$ Menurut Chin Peng di dalam Memoirnya, pembunuhan tiga peladang kulit putih di Sungai Siput dilakukan bukan dari arahan beliau tetapi dilakukan oleh sepasang suami isteri yang membalas dendam terhadap Inggeris. Peristiwa di Sungai Siput itu merupakan kesalahan serius PKM yang mengagalkan usaha PKM untuk mengundurkan kader-kader PKM secara sulit ke dalam hutan dan menyusun jaringan gerakan bawah tanahnya dengan baik. Peristiwa ini telah digunakan oleh Inggeris untuk menguatkuasakan perintah darurat pada 18 Jun 1948 dan pada 20 Jun 1948 dilakukan tangkapan beramai-ramai terhadap orang yang disyaki komunis dan PKM diharamkan (Chin Peng, My Side of History, Singapore: Media Masters, 2003 ).

32 Mohammad Agus Yusoff, Malaysian Federalism: Conflict or Consensus, Bangi: Penerbit Universiti Kebangsaan, 2006, hlm. 56.

${ }^{33}$ Khong Kim Hoong, Merdeka!, hlm. 153-154.

${ }^{34}$ Lihat Memorandum on the Constitutional Proposals for Malaya by Pan-Malayan Chinese Chambers of Commerce, 1947, hlm. 5, Arkib Negara Malaysia.

${ }^{35}$ Ibid., hlm. 12.

${ }^{36}$ Ibid., hlm. 13.

37 Ibid., hlm. 6.

${ }^{38}$ Khong Kim Hoong, Merdeka!, hlm. 156.

${ }^{39}$ Rejeswary Ampavanar, The Indian Minority, hlm. 91.

40 Pada tahun 1951, kerajaan Inggeris telah membuat pindaan terhadap Perjanjian Perlembagaan Persekutuan berhubung dengan syarat kerakyatan Persekutuan yang agak liberal dari sebelumnya (Perjanjian Persekutuan 1948) walaupun masih tidak memuaskan hati orang bukan Melayu. Dengan pindaan ini telah membolehkan hampir separuh dari orang Cina yang tinggal di Tanah Melayu memperolehi kerakyatan (Lihat, Oong Hak Ching, Chinese Politics in Malaya, hlm. 157-158).

${ }^{41}$ Heng Pek Koon, Chinese Politics in Malayasia, hlm. 47.

42 Ibid., hlm. 148.

${ }^{43}$ Ibid., hlm. 150

${ }^{44}$ Lihat surat Tan Cheng Lock kepada kawannya di Kuala Lumpur bertarikh 19 Januari $1950 \mathrm{dlm}$. A Collection of Correspondence by Dato' Sir Tan Cheng Lock, Singapore: The Singapore Tiger Standard Press, t.trkh. hlm. 14-17. Jawatankuasa CLC telah membuat cadangan sesiapa saja boleh menjadi rakyat Raja Melayu mengikut syarat-syarat seperti berikut:

1. Seorang daripada kaum asli yang menduduki di dalam negeri itu dan juga seorang Melayu yang diberanakkan sama ada di dalam ataupun di luar negeri itu dengan syaratnya pada masa ia diperanakkan maka ibu atau bapanya ialah raakyat Raja negeri itu.

2. Seorang yang berketurunan daripada bangsa Asia ataupun bangsa Eurasian yang diperanakkan di dalam negeri sebelum atau pun pada atau kemudian hari yang ditetapkan dengan syaratnya salah seorang daripada ibu atau bapanya telah diperanakkan di dalam negeri itu.

3. Seorang yang berketurunan bangsa Asia ataupun bangsa Eurasian yang diberanakkan di dalam negeri sebelum atau pun pada atau kemudian daripada 
hari yang ditetapkan itu sungguhpun ibu atau bapanya tidak diperanakkan di negeri itu dengan syaratnya seorang itu mengambil sumpah taat setia dan didaftarkan pula telah mengambil sumpah itu.

4. Seorang yang menjadi ibu atau bapa seorang yang menjadi rakyat Raja menurut Fasal 9(2) di atas, sekalipun ia tidak diperanakkan di dalam negeri itu dengan syaratnya seorang itu adalah mengangkat sumpah taat setia dan sumpahnya itu didaftarkan.

5. Seorang yang belum cukup umurnya dengan syaratnya pada waktu ia diperanakkan maka bapanya ialah rakyat Raja negeri itu (Lihat Perisytiharan Oleh Jawatan Kuasa Perhubungan Kaum (CLC), Arkib Negara Malaysia).

${ }^{45}$ CO 717/183 dipetik dlm. Mohd. Ashraf Ibrahim, Gagasan Bangsa Malayan yang Bersatu 1945-57, Bangi: Penerbit Universiti Kebangsaan, 2004, hlm. 131-132.

${ }^{46}$ Oong Hak Ching, Chinese Politics in Malaya, hlm. 157.

${ }^{47}$ Nik Mahmod Hj. Abdul Majid Kelantan, "Satu Rupabangsa Bagi Tanah Melayu", Warta Negara, 10 Mei 1950.

${ }^{48}$ Laporan UMNO Sepuloh Tahun 1946-1956, hlm. 56.

${ }^{49}$ Lihat ucapan Dato Onn' Jaafar dlm. Majlis Tergempar Mesyuarat Agung UMNO di Hotel Majectic, Kuala Lumpur pada 20 dan 21 Mei 1950. Dipetik dlm. Mohamed Abid, Imbasan Peristiwa-peristiwa Sebelum Kemerdekaan Malaya, Tri. Shajaratuddur S.Abdul Halim \& Syed Ali Tawfi al-Attas, Kelana Jaya: Pelanduk Publication (M) Sdn. Bhd., hlm. 326.

${ }^{50}$ Ibid., hlm. 327.

${ }^{51}$ Ucapan Dato' Onn di Majlis Mensyuarat Agung Khas UMNO, di Hotel Majestic, Kuala Lumpur, pada 10 dan 11 Jun 1950, dipetik dlm. Ibid., hlm. 335.

${ }^{52}$ Laporan UMNO Sepuluh Tahun 1946-1956, hlm. 64-65.

${ }^{53}$ Ibid., hlm. 67-68.

${ }^{54}$ Lihat Federation of Malaya Agreement (Amendment) Ordinance, 1952, Article 125 , 126, 131; Lihat juga, K.J. Ratnam, Communalism and the Political Process, hlm. 84-86.

${ }^{55}$ K.J. Ratnam, Communalism and the Political Process, hlm. 89.

${ }^{56}$ Khong Kim Hoong, Merdeka! hlm. 252.

${ }^{57}$ Heng Pek Koon, Chinese Politics in Malaysia, hlm. 155.

${ }^{58}$ Ucapan Tan Cheng Lock di Annual General Committee of the Malayan Chinese Association in Singapore, pada 27 Disember, 1953.

${ }^{59}$ Ramlah Adam, Biografi Politik Tunku Abdul Rahman, hlm. 207.

${ }^{60}$ Umpamanya, Dr. Buhanuddin al-Helmy yang menerajui PAS dan Dato' Onn Jaafar yang memimpin Parti Negara telah membidas UMNO kerana bersetuju dengan prinsip kerakyatan berasaskan jus soli kepada orang bukan Melayu. Dato' Onn melihat UMNO telah menyeleweng dari dasar politiknya yang sentiasa menjaga kepentingan orang Melayu. Dalam kalangan ahli UMNO juga terdapat rasa tidak puas hati. Ada yang keluar dari UMNO kerana membantah tindakan tersebut (Lihat Ramlah Adam, Sejarah Perkembangan Pilihanraya Era Pra-Merdeka, 1955, Melaka: Institut Kajian sejarah dan Patriotisme Malaysia, hlm.29.

${ }^{61}$ Mengenai isu pendidikan, Manifesto Perikatan menyatakan "...menggalakkan perkembangan sekolah-sekolah, bahasa-bahasa dan kebudayaan tiap-tiap bangsa yang tinggal di dalam negeri ini; mengkaji undang-undang Pelajaran tahun 1952 dan Kertas Putih tentang Majlis Mesyuarat Undang-undang Federal No. 67 tahun 
1954..."(Lihat "Menuju Merdeka dalam 4 Tahun", Manifesto Perikatan Dalam Pilihan raya Federal 1955).

${ }^{62}$ Heng Pek Koon, Chinese Politics in Malaysia, hlm. 207.

${ }^{63}$ Harry Miller, Putera Diraja dan Perdana Menteri, Kuala Lumpur:Federal Publication Limited, t. tarikh., hlm. 232-234.

${ }_{64}$ "Menuju Merdeka dalam 4 Tahun", Manifesto Perikatan dalam Pilihan raya Federal 1955, hlm. 34.

${ }^{65}$ Dalam usaha Perikatan untuk menghasilkan draf memorandum tersebut, mereka telah mewujudkan dua Jawatankuasa. Jawatankuasa pertama (dianggotai pemimpin senior parti) terdiri daripada Tunku Abdul Rahman, Datuk Abdul Razak, Dr. Ismail abdul Rahman, Ismail Mohamed Ali, Mohamed Khair Johari, Abdul Khair Shamsuddin, Abdul Aziz Ishak dan Mohamed Daud (semuanya dari UMNO); H.S. Lee, Leong Yew Koh, Ong Yoke Lin, Tan Siew Sin, Dr. Lim Chong Eu, Ng Ek Teong, Too Joon Hing, Yong Pung How dan T.H. Tan (MCA); V.T. Sambanthan, K. Ramanathan, K.L. Devaser, B. Kaher Singh, V. Manickavasagam dan A. Krishnadas (MIC). Manakala Jawatankuasa kedua pula terdiri dari Abdul Kadir Shamsuddin, Senu Abdul Rahman (UMNO), Ong Yoke Lin, Y.C. Kang (MCA), K. Ramanathan dan A. Krishna Dass (MIC) (Lihat Heng Pek Khoon, Chinese Politics in Malaysia, hlm. 222; Joseph M. Fernando, The Making of the Malayan Constitution, Monograph No. 31, The Malaysian Branch of the Royal Asiatic Society, 2007, hlm. 68).

${ }^{66}$ Lihat Fail UMNO/SUA No. 108/1956, Memorandum to the Reid Constitutional Commission, 27 September 1956.

${ }^{67}$ Heng Pek Koon, Chinese Politics in Malaysia, hlm. 225.

${ }^{68}$ Ibid., hlm. 241.

${ }^{69}$ Qalam, Bil. 71, Jun 1956.

${ }^{70}$ Lihat ucapan Tunku Abdul Rahman mengenai "Hak Istimewa Orang Melayu" dlm. Tunku Abdul Rahman, Malaysia: The Road to Independence, Subang Jaya: Pelanduk Publications, 2007, hlm. 90.

${ }^{71}$ Ibid., hlm. 92.

${ }^{72}$ Harry Miller, Putera Di-Raja dan Perdana Menteri, hlm. 285.

${ }^{73}$ Federation of Malay Constitution Commission 1956-1957, hlm. 14.

${ }^{74}$ Ibid., hlm. 14.

${ }^{75}$ Ibid., hlm. 15-16.

${ }^{76}$ Ibid., hlm. 16.

${ }_{77}$ K.J. Ratnam, Communalism and the Political Process, hlm. 97.

${ }^{78}$ Dipetik dlm. Ramlah Adam, Biografi Politik Tunku Abdul Rahman, Kuala Lumpur: Dewan Bahasa dan Pustaka, 2004, hlm. 276.

${ }^{79}$ Ramlah Adam, Dato' Onn: Pengasas Kemerdekaan, Cet. 5, Kuala Lumpur: Dewan Bahasa dan Pustaka, 2005, hlm. 350.

${ }^{80}$ Akhbar Kritik adalah wadah yang digunakan oleh Dato' Onn selepas beliau menubuhkan Parti Negara bagi menyalurkan aspirasi perjuangannya. Akhbar ini mula diterbitkan pada 1 A pril 1956, dikeluarkan seminggu sekali pada setiap hari Sabtu, sebagai akhbar mingguan. Ia diterbitkan oleh Warga Publishing Ltd., kepunyaan Haji Ahmad Mansor yang simpati dengan Dato' Onn yang tidak mempunyai kerja tetap. Beliau dilantik sebagai pengarang tunggal akhbar tersebut yang mempunyai 12 halaman saja (Lihat ibid., hlm. 341). 
${ }^{81}$ Ibid.

82 Persatuan Islam Sa-Malaysia (PAS), Ulasan terhadap Penyata Perlembagaan Suruhanjaya Reid, 2 Mei 1957.

${ }^{83}$ Utusan Melayu, 18 Mac 1957.

${ }^{84}$ Kritik, 20 Mac 1957.

${ }^{85}$ Ibid.

${ }^{86}$ The Malay Mail, 4 Mac 1957.

${ }^{87}$ Kritik, 20 Mac 1957.

${ }^{88}$ The Malay Mail, 11 Mac 1957.

${ }^{89}$ The Malay Mail, 21 Februari 1957.

${ }^{90}$ Dipetik dlm. Joseph M. Fernando, The Making of the Malayan Constitution, hlm. 148.

${ }^{91}$ Lihat ucapan Tunku Abdul Rahman dlm. Ibrahim Mahmood, Sejarah Perjuangan Bangsa Melayu, hlm. 564-567.

92 Tindakan menarik diri wakil-wakil UMNO N. Sembilan dari Persidangan Agong UMNO pada 28 Mac 1957 disifatkan oleh Setiausaha Agong UMNO, Datuk Senu Abdul Rahman sebagai satu sikap dan contoh yang buruk dalam lapangan demokrasi, setelah usul yang mereka bawa ditolak kerana tidak mendapat sokongan. Pada 2 April, 1957, Pejabat Setiausaha Agung UMNO telah menulis surat kepada Setiausaha UMNO N. Sembilan meminta beliau memberi kenyataan penuh sebab-sebab yang membawa perwakilan UMNO N. Sembilan keluar dari persidangan tersebut. Ahli-ahli Jawatankuasa UMNO N. Sembilan dan wakilwakil UMNO N.Sembilan yang menghadiri persidangan itu juga diminta menyatakan perasaan kesal dan dukacita mereka terhadap tindakan tersebut. Sekiranya mereka, enggan, maka tindakan disiplin akan dikenakan ke atas mereka (Lihat UMNO/SUA-28/57, Perhimpunan Agong Khas UMNO Pada 28 Mach 1957).

${ }^{93}$ Ibrahim Mahmood, Sejarah Perjuangan Bangsa Melayu, hlm. 567-569.

${ }^{94}$ Lihat, UMNO/SU 154/56 dan CO 1030/524 (30), MacGillivary to the Secretary of State, 8 April 1957, dipetik dlm. Joseph M. Fernando, The Making of the Malayan Constitution, hlm.154.

${ }^{95}$ UMNO-S-SP (50-A) 60/55, Tambahan2 Kapada Perlembagaan P.T. Melayu.

${ }^{96}$ The Malay Mail, 15 Mac 1957. 